\title{
ACCOMMODATING THE INTERESTS OF DEVELOPING Countries in The Climate Change Regime: LESSONS FROM THE OZONE LAYER REGIME
}

\author{
Mulugeta Getu *
}

\begin{abstract}
The problem of climate change has attracted international attention mainly because of its cross-border effects and the impossibility of solving the problem by a few nations. The delay in combating climate change is attributable to various factors including polarized interests among nations. On the other hand, the Montreal Protocol (ozone depletion) regime has managed to balance and reconcile the interests of both the global South and the global North towards a common goal. Even if some differences exist between the two problems, lessons from the ozone depletion regime can inform the climate regime and enhance the participation of developing nations without adversely affecting their interests. The lessons include a sequential approach [i.e. addressing the most critical issue -emission from developed countries - first], increased participation and compliance, improved financial assistance and technology transfer regimes and enhanced political commitment to climate change. These lessons are in tune with the principle of common but differentiated responsibilities which should facilitate a meaningful participation from developing countries in the climate change regime.
\end{abstract}

\section{Key words}

Climate change, Kyoto Protocol, Montreal Protocol, ozone depletion, sequential approach, technology transfer, technical assistance

DOI

http://dx.doi.org/10.4314/mlr.v6i1.1

\section{Acronyms and Abbreviations}

CDM Clean Development Mechanism

CFCs Chlorofluorocarbons

GATT General Agreement on Tariffs and Trade

GEF Global Environmental Facility

GHGs Greenhouse gases

HCFC Hydro-chlorofluorocarbons

\footnotetext{
* Mulugeta Getu, Lecturer and Associate Dean, Haramaya University College of Law, LLB (Haramaya University) LLM (University of Alabama). I would like to thank Professor William Andreen, Dr. Richard Wentzell and Brooke Glass O'shea for their comments on an earlier version of this article which was part of an unpublished research. Email: <mulugetagetu23@yahoo.com>
} 


$\begin{array}{ll}\text { HDI } & \text { Human Development Index } \\ \text { IPCC } & \text { Intergovernmental Panel on Climate Change } \\ \text { KPAF } & \text { Kyoto Protocol Adaptation Fund } \\ \text { LDCF } & \text { Least Developed Countries Fund } \\ \text { MEAs } & \text { Multilateral Environmental Agreements } \\ \text { ODSs } & \text { Ozone Depleting Substances } \\ \text { REDD } & \text { Reduced emissions from deforestation and degradation } \\ \text { SCCF } & \text { Special Climate Change Fund } \\ \text { UNDP } & \text { United Nations Development Programme } \\ \text { UNEP } & \text { United Nations Environment Programme } \\ \text { UNFCCC } & \text { UN Framework Convention on Climate Change }\end{array}$

\section{Introduction}

Environmental problems are increasingly becoming the subject of global concern owing to their cross-border effects, and because it is also impossible for one or a few nations to solve these problems on their own. ${ }^{1}$ However, a global consensus on how to solve these environmental problems and define the respective obligations of nations is not easy. ${ }^{2}$ Ozone layer depletion and climate change are typical examples in this regard.

The achievements in the climate change and ozone depletion regimes are not comparable. The ozone depletion regime is "recognized as a landmark accord in the most effective international environmental regime to date"3 and it is frequently "hailed as the most successful environmental treaty ever devised," In contrast, the climate change regime has continued to be in "the forefront of public debate" for its failure to bring about effective solutions. ${ }^{5}$ Thus, many

${ }^{1}$ This is best described by the principles of 'interdependency of ecosystem', 'common concern of mankind', and 'common heritage of mankind' all calling for the global cooperation. See Principles 4, 21-26 of the Declaration of the United Nations Conference on The Human Environment, (1972), Stockholm.

${ }^{2}$ Susskind identifies the traditional North-South split, national sovereignty and lack of incentives as the three basic obstacles for global cooperation. Lawrence E. Susskind (1994). Environmental Diplomacy: Negotiating More Effective Global Agreements, 18 (Oxford University Press, NY, Oxford,).

${ }^{3}$ Laura Thoms (2003). 'A Comparative Analysis of International Regimes on Ozone and Climate Change with Implications for Regime Design', 41 Columbia Journal of Transnational Law 795, at 795.

${ }^{4}$ Richard E. Benedick, (1998). Ozone Diplomacy: New Directions in Safeguarding the Planet, 1 (Cambridge: Harvard University Press: 2nd ed.).

${ }^{5}$ Bryan A. Green, (2009). 'Lessons from the Montreal Protocol: Guidance for The Next International Climate Change Agreement', 39 Environmental Law 253, at 254. 
successful elements of the ozone depletion regime, including the negotiation process and devices used to ensure the participation and meaningful contribution of developing nations, could perhaps serve as a model for future climate change negotiations. ${ }^{6}$

The traditional North-South divide, which presents enormous challenges to the adoption of many multilateral environmental agreements (MEAs) due to economic disparities, is one of the reasons for the delays that have occurred in fighting climate change. ${ }^{7}$ However, the Montreal Protocol regime, which deals with ozone layer depletion, is considered by many as a breakthrough in many respects, partially because it managed to balance and reconcile the interests of both the developing South and the developed North and brought both groups together to achieve a common goal. ${ }^{8}$ Based on scholarly literature, international agreements, decisions and reports, and other empirical data, this article assesses the kinds of lessons one can draw from the Montreal Protocol regime for application to the developing climate change regime. In particular, it addresses the ways in which the interests and commitments of the developing and developed nations were balanced by the Montreal regime.

Section 1 highlights the origin and features of ozone depletion and climate change and further explores the actions taken by the international community to address these environmental hazards including the negotiations, challenges encountered and the degree of success attained in the two regimes. The second section of the article focuses on the concerns raised by developing countries and their reasons for claiming preferential treatment in MEAs, the mechanisms devised by the Montreal regime to address these concerns, and the degree of success such mechanisms have had. Moreover, some differences and similarities of the two regimes are discussed with a view to identifying the lessons that contributed to the success of the Montreal regime. Section 3 assesses the lessons that can safely be applied to the climate regime through global consensus that requires enhanced participation of developing nations without adversely affecting their interests. Hence, a sequential approach [addressing the

${ }^{6}$ Id; Laura Thoms, supra note 3, at 795; Sean Cumberlege, (2009). 'Multilateral Environmental Agreements: From Montreal to Kyoto - a Theoretical Approach to an Improved Climate Change Regime', 37 Denver Journal of International Law and Policy 303, at 304.

${ }^{7}$ See for example, Harro van Asselt and Joyeeta Gupta, (2009). 'Stretching Too Far? Developing Countries and The Role Of Flexibility Mechanisms Beyond Kyoto', 28 Stan. Envtl. L.J. 311; Michael Weisslitz, , (2002). Comment, 'Rethinking the Equitable Principle of Common but Differentiated Responsibility: Differential Versus Absolute Norms of Compliance and Contribution in the Global Climate Change Context', 13 Colo. J. Int'l Envtl. L. \& Pol'y 473.

${ }^{8}$ Weisslitz, Ibid, at 480. 
most critical issue -emission from developed countries - first], increased participation and compliance, improved financial assistance and technology transfer regimes, and enhanced political commitment to climate change are discussed in relation to the climate change regime.

\section{Development of the Ozone Layer and Climate Change Regimes}

\subsection{Ozone Layer Protection}

The second layer of the atmosphere, the stratosphere, contains a high amount of ozone $\left(\mathrm{O}_{3}\right)$ and is called the ozone layer. ${ }^{9}$ In the absence of human interference, there is the natural balance between the formation and destruction of stratospheric ozone. ${ }^{10}$ Ozone depletion, therefore, occurs when more ozone is destructed than is created, resulting in a thinning of the ozone layer. ${ }^{11}$ The importance of stratospheric ozone lies in its ability to reflect ultraviolet (UV-B) radiation from the sun and thus prevent much of it from reaching the earth. ${ }^{12}$ According to the UNEP Environmental Effects Assessment Panel Report for 2006, an increase of ultraviolet radiation can produce an increase in cataracts and pterygium, more skin cancer, and diminished immune responses to infectious agents, adverse effect to terrestrial and aquatic ecosystems, and also to plastics and wood materials. ${ }^{13}$

\footnotetext{
${ }^{9}$ Ozone Secretariat, United Nations Environment Programme (UNEP 2000), Action on Ozone, Edition, Kenya Nairobi, at 1, [here after Action on Ozone] http://ozone.unep.org/pdfs/ozone-action-en.pdf/ last visited on July 10, 20112. See also US EPA (Environmental Protection Authority), Office of Research and Development, Stratospheric Ozone Depletion: A Focus on EPA's Research, at 2-3. Available at http://www.epa.gov/Ozone/science/effects/index.html/ last visited on September 10, 2011.

${ }^{10}$ See, Id.

${ }^{11}$ See, Id.

12 The Environmental Effects Assessment Panel Report for 2006, (2006): FAQs, Questions and answers about the effects of the depletion of the ozone layer on humans and the environment, at 5. www.ozone.unep.org/Assessment_Panels/EEAP/eeap-report2006-FAQ.pdf/ last visited on July 10, 2012.

${ }^{13}$ UNEP, Ozone Secretariat, (2006). The Environmental Effects Assessment Panel Report for 2006, at xv and 26- 200, [hereafter The Environmental Effects Assessment Panel Report 2006] http://ozone.unep.org/Assessment_Panels/EEAP/eeapreport2006.pdf, last visited on August 20, 2009; EPA, Health and Environmental Effects of Ozone Layer Depletion, available at
} 
The scientific evidence accumulated over more than three decades shows that human-produced chemicals, called ozone depleting substances (hereafter "ODSs"), like chlorofluorocarbons (hereafter "CFCs") and halons, are responsible for the observed depletions of the ozone layer. ${ }^{14}$ Scientific uncertainty about its harm and cause, unequal contribution by nations, potentially high transition costs and unavailability of alternatives to the many uses of ODSs, unequal capacity to bear the cost of providing relief, and the global nature of the problem that deserves national cooperation were some of the challenges surmounted to bring about a regulatory multilateral environmental treaty. ${ }^{15}$ Yet, several countries and non-governmental organizations ("NGOs") called for an international action towards a precautionary approach in the protection of the atmosphere, ${ }^{16}$ which later on resulted in the Vienna Convention for the Protection of the Ozone Layer (Vienna Convention hereafter) in 1985. ${ }^{17}$

The convention did not include specific provisions and commitments regarding ODSs and it did not even determine which substances are responsible for ozone depletion mainly owing to the scientific uncertainties and economic factors. Yet, it has played a significant role in establishing a legal framework and setting the basic principles for subsequent negotiations. ${ }^{18}$ The Vienna Convention, together with advanced scientific findings and human understanding of the threat ultimately paved the way for the development of the Montreal Protocol and the subsequent amendments and adjustments.

http://www.epa.gov/Ozone/science/effects/index.html/ last visited on September 10,2011 .

${ }^{14}$ UNEP, (2005). Backgrounder: Basic Facts and Data on the Science and Politics of Ozone Protection, at 1; see also, The United Nations Ozone Secretariat UNEP, (2007). Montreal Protocol on Substance that Deplete the Ozone Layer 2007: A Success in the Making, at 2; Hunter, Salzman and Zaelke, (2007). International Environmental Law and Policy, 566-569 and 572-573 (West Publishing, $3^{\text {rd }}$ Ed.) [here after Hunter et al].

${ }^{15}$ Hunter et al, Ibid, at 567.

${ }^{16}$ Lee Anne Duval, (1999). 'The Future of the Montreal Protocol: Money and Methyl Bromide', 18 Virginia Environmental Law Journal 609. However, some nations like USA, Canada, and the Scandinavian have taken action to ban the non-essential use of CFCs such as aerosol propellants in the late 1970s. Due to voluntary switching and later federal regulation, CFCs have been banned in US aerosol products in the USA since the late 1970s. Hunter et al, supra note 14, 576-77; US Environmental Protection Authority, Ozone Layer Protection Glossary, available at http://www.epa.gov/ozone/defns.html last visited on July 10, 2012;

${ }^{17}$ Green, supra note 5; Hunter et al, supra 14, at 578.

${ }^{18} \mathrm{Id}$. 
The Montreal Protocol is built upon the principles of 'Precaution' and 'Common but Differentiated Responsibility,' and it has addressed the gaps in the Vienna Convention. ${ }^{19}$ More importantly, the Protocol has created institutional mechanisms that would adjust commitment levels and payoff structures in response to unforeseen developments without requiring new renegotiation. ${ }^{20}$ Since 1987, the parties to the Montreal Protocol have successfully negotiated six amendments or/and adjustment documents commensurate with the advancement in scientific knowledge about ozone depletion. $^{21}$ Richard Benedick, the chief U.S. negotiator to the Montreal Protocol, acknowledged that the Montreal Protocol was designed to be flexible, "to be reopened and adjusted as needed, on the basis of the periodically scheduled scientific, economic, environmental, and technological assessments. $" 22$

The Montreal Protocol regime is considered as an exciting success. ${ }^{23}$ The total number of controlled substances reached $96^{24}$ and the 2006 UNEP

${ }^{19}$ Montreal Protocol on Substances that Deplete the Ozone Layer, (adopted on Sept. 16, 1987), 26 I.L.M. 1541, 1543 (entered into force Jan. 1, 1989) [hereinafter Montreal Protocol], preamble, para 4-8. The Montreal Protocol, inter alia, required parties to co-operate in promoting research, development and exchange of information, listed five CFCs and three halons as ODSs with restrictions on production and consumption, and required parties to submit annual report on the same. The agreement also included implementation mechanisms and incentives in the form of trade restrictions, and a more flexible reduction scheme like the "basket strategy." see also Hunter, supra note 14, at 583-585.

${ }^{20}$ Hunter et al,, supra note 14, at 586; See also Leonard V.B. Sutton Award, (2009). Multilateral Environmental Agreements: From Montreal to Kyoto - A Theoretical Approach to an Improved Climate Change Regime, 37 Denver Journal of International Law and Policy 303.

${ }^{21}$ UNEP Ozone Secretariat, The Montreal Protocol on Substances that Deplete the Ozone Layer, as either adjusted and/or amended in, London 1990, Copenhagen 1992, Vienna 1995, Montreal 1997, Beijing 1999, annex A - E, 2000. Available at http://ozone.unep.org/new_site/en/index.php_lasted visited on July 10, 2012.

${ }^{22}$ Benedick, supra note 4, at 99 .

${ }^{23}$ Its universal acceptance can also be mentioned as a success and as of May 2009, 196 countries are parties to the convention and the protocol (including Ethiopia), 196 to London, 194 to Copenhagen, 185 to Montreal and 169 to Beijing amendments. Ozone Secretariat UNEP site, http://montrealprotocol.org/new_site/en/treaty_ratification_status.php/ last visited on July 10, 2012.

${ }^{24}$ Lauren Kelly (2004). The Multilateral Fund for the Implementation of the Montreal Protocol Addressing Challenges of Globalization: An Independent Evaluation of the World Bank's Approach to Global Programs, Case Study, 3 (The World Bank, Washington, D.C.). 
assessment report shows that the depleted ozone was showing signs of recovery. ${ }^{25}$ It is also estimated that with continued compliance with the current control measures of the Protocol, global average ozone is expected to return to pre-1980 levels by about $2050 .{ }^{26}$ The regime also "[s]ecured an aggregate $95 \%$ reduction in production and consumption of all ozone-depleting substances" thereby achieving "a measurable reduction in tropospheric and stratospheric levels of many ozone-depleting substances." 27 The cost incurred in its mitigation is much lower than the benefit gained in terms of avoided human and material losses. $^{28}$

\subsection{Climate Change}

When the heat that comes from the sun is radiated back by the earth's surface to the atmosphere, greenhouse gases $(\mathrm{GHG})^{29}$ absorb some of this heat keeping the Earth warmer: at present, about $15^{\circ} \mathrm{C} .{ }^{30}$ But human activities are now causing atmospheric concentrations of greenhouse gases to rise, forcing it to absorb more heat thereby increasing average global temperature. ${ }^{31}$ Consequently, the

${ }^{25}$ UNEP, (2007). Synthesis Summary - Presentation of the synthesis report of the 2006 assessments of the Scientific Assessment Panel, the Environmental Effects Assessment Panel and the Technology and Economic Assessment Panel, at 4.

${ }^{26}$ Id.

${ }^{27}$ UNEP, Ozone Secretariat, (2007). Summary of issues for discussion at the dialogue on key future challenges to be faced by the Montreal Protocol, 3 (Nairobi). $<\mathrm{http}$ //ozone.unep.org/Meeting_Documents/dkfc/1dkfc/index.shtml/> Last visited on July 10, 2012.

${ }^{28}$ Globally [projected to cover 1987-2060] the regime is able to avoid 20.6 million skin cancer cases, 333,500 cancer deaths, 129.1 million cataracts which totally become around US\$ 672 billion monetized benefits and additional US\$ 459 billion non-health benefits only with the cost of US\$235 billion. The cost benefit analysis for USA alone shows US\$ 21 billion costs but US\$ 3,575 billion monetized benefits. Cass R. Sunstein, (2007). 'Of Montreal and Kyoto: A Tale of Two Protocols', 31 Harv. Envtl. L. Rev. 1, at 17-19.

${ }^{29}$ Jane A. Leggett, (2007). Climate Change: Science and Policy Implications, Updated May 2, 2007, Congressional Research Service (CRS) Report for Congress, Order Code RL33849, at 22.

${ }^{30}$ The Causes of Global Climate Change, (2008). Science Brief 1 Updated August 2008 [Science Brief here after], at 1; Edward A. Page, (2006). Climate Change, Justice and Future Generations, 23 (Edward Elgar Publishing Limited, Cheltenham, UK,).

${ }^{31}$ Intergovernmental Panel on Climate Change, Fourth Assessment Report, (2007). Climate Change 2007: Synthesis Report, Summary for Policymakers 20, http://www.ipcc.ch/pdf/assessment-report/ar4/syr/ar4_syr_spm.pdf. Last visited on September 13, 2011. Carbon dioxide levels alone have increased from $280 \mathrm{ppm}$ (parts 
2007 assessment report of the Intergovernmental Panel on Climate Change (IPCC) concluded that warming is unequivocal, and "very likely" (with 90\%$95 \%$ probability than the $66 \%-90 \%$ probability in 2001) that warming is due to human activity. ${ }^{32}$

The effects of climate change include increase in global mean temperature [commonly referred to as global warming], increase in global precipitation in many parts of the world, and precipitation decrease in the sub-tropics, such as the Sahel in Africa, and increase in frequency or intensity of climate extremes such as floods, drought and tropical cyclone. ${ }^{33}$ Scientists strongly suggest that we should not let global temperatures rise by more than $2^{\circ} \mathrm{C}$ to $2.5^{\circ} \mathrm{C}$ total above pre-industrial levels for mitigating these sufferings. ${ }^{34}$

With an increased public awareness and enhanced concern about climate change, the international dialogue initiated by the UN and other international organizations $^{35}$ has resulted in the UN Framework Convention on Climate Change (UNFCCC) in $1992 .{ }^{36}$ As an interim measure, UNFCCC imposed a

per million) in 1750 to over $375 \mathrm{ppm}$ today, and methane and Nitrous oxide $\left(\mathrm{N}_{2} \mathrm{O}\right)$ have increased by about $150 \%$ and $16 \%$ respectively since the Industrial Revolution

32 John C. Dernbach and Seema Kakade, (2008). 'Climate Change Law: An Introduction', Energy Law Journal, Vol. 29 No.1, 3-4. Anthropogenic emission includes from power plants and vehicles, aviations coming from fuel consumption and water vapor, land surface changing and land clearing. Jane A. Leggett, supra note 29, at 3; Science Brief, supra note 30, at 5.

33 See Jane A. Leggett, supra note 29, at 10-12, 19, 37; World Meteorological Organization, (2006). "Statement on Tropical Cyclones and Climate Change" Report of the International Workshop on Tropical Cyclones" IWTC-6. Included are externalities like increase in heat-related diseases, changes in phenologies of species and its special distribution, pest outbreaks and fire, the melting of glaciers and ice packs, increases in sea level, etc.

34 European Commission 2007; UNSEG 2007; International Scientific Steering Committee 2005; World Development Report 2010 Development in a Changing Climate Concept note, at 8.

35 Stephen Keach and Andrea Darden, (2002). The Science of Climate Change, University of Virginia, 2 (Darden Business Publishing, UVA-ENT-0037). Especially, IPCC, which was established by UN and World Meteorological Organization, through its series of assessment reports published since 1990 triggered international action and raise public awareness.

$<$ http://www.ipcc.ch/organization/organization_history.shtml/> last visited on July 10, 2012.

${ }^{36}$ Philippe Sands, QC, (2003). Principles of International Environmental Law 359 (Cambridge University Press, $2^{\text {nd }}$ Edn). UNFCCC entered in to force in January 1994 when it was ratified by 50 countries. Robert N. Stavins and Scott Barrett, Increasing Participation and Compliance in International Climate Change Agreements, Kennedy 
non-binding goal of reducing GHGs by industrialized nations (Annex-I Countries) to their pre-1990 levels by the year 2000, though many nations failed to reach this goal. ${ }^{37}$ The Convention also calls on developed countries to "take the lead in combating climate change and the adverse effects thereof." 38 The Convention balances the economic growth needs of developing nations while combating climate change. To this end, it seeks financial assistance from developed nations so that developing countries can meet "the agreed full costs incurred by developing country parties in complying with their obligations" and the full incremental costs of technology transfer. ${ }^{39}$

The fact that it was initially signed by 161 countries, and has now been ratified by 195 , shows that there is "a strong foundation for future international binding agreements to address climate change." ${ }^{\text {" }}$ But parties to the Convention found out that commitment of parties provided under the Convention is 'inadequate' and thereby started further negotiations ${ }^{41}$ which led them to the

School of Governance, Harvard University, Working Paper No, RWP02-031, at 3: available at http://papers.ssrn.com/abstract_id=351602/.

37 United Nations Framework Convention on Climate Change, (1992). FCCC/INFORMAL/84 GE.05-62220 (E) 200705, [here after UNFCCC], Article 2. For instance, United States had surpassed $\mathrm{CO}_{2}$ targets for the year 2000 by the end of 1994. In addition, the International Energy Agency predicts that emission of the industrialized countries that make up the agency will increase by eleven to twentyfour percent over the next fifteen years and unlikely to achieve their historical 1990 levels even by the year 2010. William C. Burns, (1997). Global Warming--The United Nations Framework Convention on Climate Change and the Future of Small Island States, 6 Dick. J. Envtl. L. \& Pol'y 147, at 176-178; See also Katherine H. Regan, (2010).The Case For Enhancing Climate Change Negotiations With A Labor Rights Perspective, 35 Columbia Journal of Environmental Law 249, 253-254.

${ }^{38} \mathrm{Id}$, at Art. 3; Regan, supra note37, at 255.

${ }^{39}$ Id, at Article 4(3); Regan, supra note 37, at 255.

${ }^{40}$ United Nations Framework Convention on Climate Change, Status of Ratification, $<$ http://unfecc.int/essential_background/convention/status_of ratification/items/2631txt.php/> (Last visited September 14, 2011). This of course includes 194 countries and one regional economic organization.

${ }^{41}$ The Berlin Mandate and Geneva Ministerial Declaration are some of the examples that came after the Convention to strengthen the commitment. Conference of the Parties to the United Nations Framework Convention on Climate Change, The Berlin Mandate: Review of the Adequacy of Article 4, Paragraph 2(a) and (b), of the Convention, Including Proposals Related to a Protocol and Decisions on Follow-Up, in Report of the Conference of the Parties on its First Session, Held at Berlin from 28 March to 7 April 1995, P 2(a), FCCC/CP/1995/7/Add.1 (June 6, 1995) mentioned in Sands, supra note 36, at 369; See also Regan, supra note 37, at 255; See also Geneva 
Kyoto Protocol in 1998. ${ }^{42}$ The Kyoto Protocol requires Annex I parties (developed countries and countries with economies in transition) to reduce their emission of six $\mathrm{GHGs}^{43}$ and it provides flexible market-based mechanisms (but with less effective implementation schemes) to promote compliance and participation. ${ }^{44}$ Despite its binding targets, many are skeptical about the success

Ministerial Declaration, (1996). Annex, Report of the Conference of the Parties on its Second Session, Geneva, 8-19 July 1996, FCCC/CP/1996/15/Add.1.

42 The negotiation for Kyoto experienced contentious and tough divisions and challenges which entered into force when Russia joined the parties in 2005. But the United States maintained that the Protocol is "fatally flawed" for: (1) the extent of anthropogenic induced climate change is uncertain, (2) emissions allocation schemes that only bind Annex I countries have the potential to harm economic competitiveness, and (3) an effective collective action response requires reciprocal GHG reduction commitments from developing nations. Lisa Schenck, (2008). Climate Change "Crisis" - Struggling for Worldwide Collective Action, 19 Colorado Journal of International Environmental Law and Policy 319, at 328-29, mentioning Bush Press Conference at White House, 29 March 2001; Sands, supra note 36, at 370; 'The Bonn Agreements on the Implementation of the Buenos Aires Plan of Action', Decision 5/CP.6, Report of the Conference of the Parties on the Second Part of its Sixth Session, (2001). Bonn, 16-24 July 2001, FCCC/CP/2001/5, 36-49 and Report of the Conference of the Parties on its Seventh Session, Marrakesh, 29 October-10 November 2001, FCCC/CP/2001/13; Elizabeth Burleson, (2010). 'Climate Change Consensus: Emerging International Law', 34 William and Mary Environmental Law and Policy Review 543, 546.

${ }^{43}$ It sets for the European Community and its member states an emissions limitation of 92 per cent of the 1990 base year, or an 8 per cent reduction, the United States to a 7 per cent reduction, Japan and Canada each to a 6 per cent reduction, Australia and Iceland were permitted to make increases of respectively 8 per cent and 10 per cent, Russia, the largest emitter of the Eastern bloc countries, to stabilize its emissions at 100 per cent of 1990 levels. Sands, supra note 36, at 371-372; Kyoto Protocol to the United Nations Framework Convention on Climate Change, (1998). Dec. 10, 1997, 37 I.L.M. 22 (1998) (entered into force Feb. 15, 2005) [hereafter Kyoto Protocol], at Article 3(1).

${ }^{44}$ The most innovative, flexible and economically viable mechanisms adopted in the Protocol are the Clean Development Mechanism ("CDM"), Joint Implementation ("JI") and emissions trading ("ET") which are aimed at reducing global emission levels and facilitating the transfer of funds and technology to developing countries. CDM system allows Annex I parties to invest in emissions reductions projects in non-Annex I parties and use the certified emissions reductions (CERs) accruing from such project activities 'to contribute to compliance with part of their quantified emission limitation and reduction commitments under Article 3.' While JI allows Annex I party to transfer to, or acquire from, any other Annex I party 'emission reduction credits resulting from projects aimed at reducing anthropogenic emissions by sources or enhancing anthropogenic removals by sinks of greenhouse gases in any 
of the Kyoto Protocol in achieving targeted global reductions in GHG emissions. ${ }^{45}$ Indeed, global $\mathrm{CO}_{2}$ emissions alone are projected to increase by forty-six percent over 1990 levels by $2010^{46}$ and many parties, except some European nations, are projected to miss their assigned emission targets. ${ }^{47}$

On the other hand, negotiations and meeting of parties continued on a postKyoto regulation which aims at strengthening emission reduction commitments, which would include the US and some high-emitter developing nations, like China and India. ${ }^{48}$ Very recently, the parties at the Copenhagen Conference of 2009, failed to meet expectations and they only agreed on a non-binding instrument called the Copenhagen Accord, also known as 'a letter of intent' ${ }^{49}$ The traditional North-South dichotomy was evident in the Copenhagen Conference where China called upon the USA to live up to its obligation assumed by the UNFCCC in significantly reducing emission and providing financial assistance to the developing nations, while the US called for developing nations to assume their own commitments. ${ }^{50}$ Despite all these efforts, the existing climate regime still lacks at least (1) a binding emission reduction schedule for nations, including reduced emissions from deforestation

sector of the economy'; Emissions trading, on the other hand, permits an Annex B party to 'buy' emissions reduction credits, in the form of assigned amounts units from another Annex B party where it considers this is more cost-effective or cheaper for it rather than to undertake the reduction domestically. Stavins and Berrett, supra note 36, at 2; Kyoto Protocol, supra note 43, Article 12, 16 and 17; Petra Lea Láncos, (2008). Flexibility And Legitimacy - The Emissions Trading System Under The Kyoto Protocol, 9 German Law Journal 1625, at 1637-38; Sands, supra note 36, at 373; Regan, supra note 37, at 256.

${ }^{45}$ Cass R. Sunstein, supra note 28 , at 4-5.

46 Christopher E. Angell, (2010). 'Assessing Climate Agreement Principles: The Tension Between Early Equivalent Actions and Variable Costs', 35 Columbia Journal of Environmental Law 213, at 220.

${ }^{47}$ For example, Canada will miss its target of $6 \%$ reduction below 1990 levels, with its emissions 30\% percent above its Kyoto Protocol target level as of 2007; Japan will need to purchase significant offsets through the Clean Development Mechanism and other trading provisions of the Protocol to meet its target. But Europe has had ongoing emissions reduction progress yet many expected it to miss its Protocol targets. Id, at 220; Cass R. Sunstein, supra note 28, 36-38.

${ }^{48}$ Id; See Daniel Bodansky, (2010). 'The Copenhagen Climate Change Conference: A Postmortem', 104 Am. J. Int'l L. 230, 230.

${ }^{49}$ Elizabeth Burleson, supra note 42, at 548;

${ }^{50} \mathrm{Id}$, at 547 . USA also offered its 2005 emission to be used as a baseline instead of 1990 while Australia offered 2001 instead. 
and degradation (REDD), ${ }^{51}$ (2) details on financial support and technology transfer, and (3) agreements on monitoring, reporting, and verification. ${ }^{52}$

\section{Interests of Developing Nations in MEAs and the Success of Ozone Layer Regime}

\subsection{Special Concerns of Developing Nations in MEAs}

The widening split between the developed North and developing South and the polarized interests thereof have prevented the international community from protecting the 'global commons. ${ }^{53}$ Developing nations, owing to different factors, claim that they bear little or no responsibility for mitigating environmental problems which are believed to have been created largely by the developed world. ${ }^{54}$ This section will describe the arguments raised by the developing South in claiming such preferential treatment in MEAs, especially in ozone and climate change regimes, and its significance in creating equity and fairness in global relations.

${ }^{51}$ COP-13 held in Bali, Indonesia for the first time outlined approaches to stimuli REDD in developing nations. Since then REDD becomes part of the climate change negotiation. The Copenhagen Accord further recognized its importance, however only called to provide positive incentive and establish mechanisms for mobilizing resources for the same without further details. UNFCCC, Conference of the Parties, Fifteenth session, Copenhagen, 7.18 December 2009, FCCC/CP/2009/L.7, December $18^{\text {th }}$ 2009, [here after Copenhagen Accord], at article 6; Daniel Bodansky, supra note 48, at 237; Melissa Farris, (2010). 'The Sound Of Falling Trees: Integrating Environmental Justice Principles Into The Climate Change Framework For Reducing Emissions From Deforestation And Degradation (REDD)', 20 Fordham Envtl. L. Rev. 515, at 520.

${ }^{52}$ Elizabeth Burleson, supra note 42, at 547; Gary Clyde Hufbauer and Jisun Kim, (2010). Global Warming: Climate Change and the Law, After The Flop In Copenhagen, SR039 American Law Institute - American Bar Association Continuing Legal Education 339, ALI-ABA Course of Study March $4-5$.

${ }^{53}$ See, Susskind, supra note 2, at 18 . The other factors are the stubborn persistence of national sovereignty, global nature of the problem, and an apparent lack of incentives sufficient to bring some nations to the bargaining table.

54 See, Mark A. Drumbl, (2002). 'Northern Economic Obligation, Southern Moral Entitlement, And International Environmental Governance', 27 Columbia Journal of Environmental Law 363; Andrew Schatz, edr, (2008). 'Foreword: Beyond Kyoto The Developing World And Climate Change', 20 Georgetown International Environmental Law Review 531, at 533. 
It is true that, historically speaking, developing countries contributed little or nothing to environmental problems, like ozone depletion and climate change. ${ }^{55}$ For instance, developed countries with less than $25 \%$ of the world's population were consuming $88 \%$ of the CFCs, which is over 20 times the per capita consumption of the developing countries. ${ }^{56}$ Similarly, developed countries are responsible for two-thirds of global carbon emissions from fossil fuel use in $1993 .^{57}$ Although there is a higher emission growth in some developing nations like China, India and Brazil in their pursuits "to meet their social and development needs", per capita carbon emissions are still lower compared to the developed world. ${ }^{58}$ Perhaps the long atmospheric lifetime of these ODSs and GHGs creates certain moral and historical responsibilities for the developed nations. ${ }^{59}$

Hence, developing nations claim that developed countries are disproportionately responsible for creating ozone depletion and climate change problems, and they should take the lead in devising the solutions as well. ${ }^{60}$ This principle of equity leads to the argument that developed nations have attained their economic growth by using ODSs and GHGs and the same opportunity

${ }^{55}$ Margaret M. Pinkham, (1991). 'The Montreal Protocol: An Effort to Protect the Ozone Layer’, 15 Suffolk Transnat'l L.J. 255, 269-270 ; Drumbl, Northern Economic Obligation, supra note 54, at 364-366.

${ }^{56}$ Hunter, supra note 14, at 590.

${ }^{57}$ IPCC tell a similar story, and estimate that developed countries were responsible for 67.8 per cent of total $\mathrm{CO}_{2}$ emissions between 1900 and 1988. It is, however, projected that by 2020 there is a high probability that developing nations' aggregate emission would surpass that of developed. For example, the projection for China alone is $19.3 \%, 20.8 \%$ and $22.2 \%$ for years 2010,2015 and 2020 consecutively while the same of USA is $21 \%, 20 \%$ and $19.4 \%$. United Nations Development Programme (UNDP) (2007). Human Development Report for 2007/2008, Fighting Climate Change: Human Solidarity in a Divided World, [here after Human Development Report], Palgrave Macmillan, NY, USA, at 7; Edward A. Page, supra note, at 168; Cass R. Sunstein, supra note 28, at 52.

${ }^{58}$ For instance, the carbon footprint of the United States is five times that of China and over 15 times that of India and in Ethiopia, the average per capita carbon footprint is 0.1 tonnes of $\mathrm{CO}_{2}$ compared with 20 tonnes in Canada. UNFCCC, supra note 37, Preamble; Id, at 7; Hunter, supra note 14, at 664.

${ }^{59}$ Edward A. Page, supra note 30, at 168. For instance, $\mathrm{CO}_{2}$ continues to contribute to global warming up to 200 years after being emitted, whereas sulphur hexafluoride contributes for 3000 years or more.

${ }^{60}$ Proceedings of the Ninety-Sixth Annual Meeting of the American Society of International Law, (2002). Common but Differentiated Responsibility, 96 Am. Soc'y Int'l L. Proc. 358, at 358. 
should be granted to developing nations. ${ }^{61}$ For this reason, during the negotiation of the London Amendment to the Montreal Protocol in 1990, India's Environmental Minister claimed that the North "had usurped India's 'opportunity' to develop CFC production" and should pay compensation for the same. ${ }^{62}$

The other related concern of developing nations is the fear that stringent environmental responsibilities might retard their economic growth and development. ${ }^{63}$ It has been noted that, "there exists a hierarchy of human needs in developing countries by which needs for food, clothing, and shelter take priority over social and aesthetic needs." ${ }^{\prime 64}$ That means, when a developing country is struggling to meet the basic needs of its population, "[p]olicies to protect the environment may not be feasible for a country dealing with overpopulation, malnutrition, and lack of basic sanitation." ${ }^{65}$ Thus, developing

${ }^{61}$ Weisslitz, supra note 7, at 480-81; Hunter et al, supra note 14, at 664-665; Edward A. Page, supra note 30, at 168. Given that most GHG and ODS remains in the atmosphere for decades, developed nations have 'banked' more than enough of their equitable share to pollute' the atmosphere. For instance, USA has emitted more than $30 \%$ of all $\mathrm{CO}_{2}$ emission over the past century and 301279 million metric tonnes in the period 1800-2000 which is roughly four times as much as the next biggest emitters, Russia (86 705) and Germany (75 606). The cumulative contribution of developing countries over this period is, by contrast, very small, for instance, the whole of Sub-Saharan Africa emitted just 17 665, and Central America and the Caribbean just 13 376, million metric tonnes of $\mathrm{CO}_{2}$. World Resources 2003-2004: Decisions for the Earth: Balance, Voice and Power (Washington DC: World Resource Institute), at 258-259 (available online at: http://governance.wri.org/).]

${ }^{62}$ Dale S. Bryk, (1991). 'The Montreal Protocol and Recent Developments to Protect the Ozone Layer', 15 Harv. Envtl. L. Rev. 275, at 291.

${ }^{63}$ Lee Anne Duval, supra note 16.

${ }^{64}$ See Bing Ling, (1992). 'Developing Countries and Ozone Layer Protection: Issues, Principles and Implications', 6 Tul. Envtl. L.J. 91, at 93-94.

${ }^{65}$ Margaret M. Pinkham, supra note 55. Thomas Franck also observed that "[n]ations like China, India, Algeria, and Brazil have argued that development, by which they usually mean industrialization, is more important to the well-being of their people than a fastidious concern for the environment." Thomas M. Franck, Fairness in International Law and Institutions (1995), at 368. Likewise, the head of the Brazilian Delegation observed that: Mankind has legitimate needs that are material, aesthetic and spiritual. A country that has not yet reached minimum satisfactory levels in the supply of essentials is not in a position to divert considerable resources to environmental protection. M. Tolba ed., (1988). Statement by Head of Brazilian Delegation in Evolving Environmental Perceptions: From Stockholm to Nairobi 51, at 135; John Ntambirweki, (1991). 'The Developing Countries In The Evolution Of 
nations are prepared to sacrifice the environment in order to increase their economic growth and raise their standard of living. ${ }^{66}$

They went far in considering some environmental regimes, like the Montreal Protocol Regime, as an instrument for the developed nations to subvert their economic development. ${ }^{67}$ The developing world is unwilling to pursue life without using the products that have ODSs, which make life much easier in its many uses. ${ }^{68}$ Likewise, there is a strong correlation between current levels of development and GHG emission. ${ }^{69}$ Early industrialization results in higher emissions, which has brought current prosperity to the developed world but not yet to the developing world. ${ }^{70}$ That is why developing nations "have not yet accepted any requirement through climate negotiation that will [may] slow down their economic growth." ${ }^{71}$ Yet they cannot pursue polluting the environment as "consensus has emerged that the planet can withstand little more of these externalities or has hit some sort of tipping point."72

This hesitation seems rational and morally coherent when one observes that developing countries simply do not have the resources to practice environment friendly economic growth due to factors such as the tremendous cost of reducing GHG emission or adaptation to it. These same costs even intimidate the wealthy nations like the US. ${ }^{73}$ Thus, the financial and technical incapability of developing countries to respond to climate change problems or produce or buy

\footnotetext{
An International Environmental Law', 14 Hastings International and Comparative Law Review 905, at 906.

${ }^{66}$ Lee Anne Duval, supra note 16.

${ }^{67} \mathrm{Id}$.

${ }^{68}$ James Andrew Bove, (2003). 'A Study of the Financial Mechanism of the Montreal Protocol on Substances that Deplete the Ozone Layer', 9 Environmental Lawyer 399; David Hurlbut, (1993). 'Beyond the Montreal Protocol: Impact on Nonparty States and Lessons for Future Environmental Protection Regimes', 4 Colo. J. Int'l Envtl. L. \& Pol'y 344, at 352.

${ }^{69}$ Philippe Cullet, (2003). Differential Treatment in International Environmental Law, 46 (Aldershot: Ashgate).

${ }^{70}$ Michael McKenzie, (2008). 'Climate Change and the Generalized System of Preferences', 11 Journal of International Economic Law 679, at 681.

${ }^{71}$ Hunter et al, supra note 14, at 664; Mark A. Drumbl, (2002). 'Poverty, Wealth, and Obligation In International Environmental Law', 76 Tulane Law Review 843, at 849.

${ }^{72}$ Id; Michael J. Kelly, (1997). 'Overcoming Obstacles to the Effective Implementation of International Environmental Agreements', 9 Geo. Int'l Envtl. L. Rev. 447, at 450 and 455 .

${ }^{73}$ E. William Colglazier, (1991). 'Scientific Uncertainties, Public Policy, and Global Warming: How Sure Is Sure Enough?', Pol'y Studies J., 61, at 65; Drumbl, Poverty, Wealth, and Obligation, supra note 71, at 849-50.
} 
the relatively expensive alternatives to ODS is a point of concern. For instance, studies revealed that accelerated phase-out schedule of methyl bromide might take away a substantial portion of food supply in developing countries. ${ }^{74}$ Hence, the fact that many of the developing countries do not have the research resources to develop alternatives, and that most of the research is occurring in the industrialized nations render it extremely difficult to subject both groups to similar phase-out schedules. ${ }^{75}$

Another argument that developing countries put forth is the "polluter pays principle." $" 76$ The principle suggests that the industrialized nations have caused the problems of pollution, and "they should pay the developing countries to avoid making the same development decisions that would further contribute to the problem." 77 For instance, in the methyl bromide debate, this principle requires developed countries to provide assistance to find alternatives so that the developing countries can continue to develop without compromising their food supply. ${ }^{78}$ After recognizing that the industrialized nations are responsible for most of the damage on the atmosphere, ${ }^{79}$ Singer claims that: "as far as the atmosphere is concerned, the developed nations broke it. If we believe that people should contribute to fixing something in proportion to their responsibility for breaking it, then the developed nations owe it to the rest of the world to fix the problem with the atmosphere." 80

${ }^{74}$ Lee Anne Duval, supra note 16. Methyl bromide is powerful ozone depleting substance or pesticide used in the control of pest insects, nematodes, weeds, pathogens, and rodents in agricultural productions equally in use in developing and developed nations. Developing countries, however, claimed that banning of methyl bromide before finding its right and economically viable substitute will benefit only the developed north where their companies will sell the expensive substitute at the price which is only affordable to their farmers.

${ }^{75}$ See Chris Hall (1997), 'Availability of Alternatives to Methyl Bromide Worries Farming Industry', 20 Int'l Env't Rep. (BNA) No. 3, at 126 (Feb. 5, 1997); see also Id

${ }^{76}$ See Anne Gallagher, (1992). "The 'New' Montreal Protocol and the Future of International Law for Protection of the Global Environment", 14 Hous. J. Int'l L. 267, at 270.

${ }^{77}$ See, Id; Lee Anne Duval, supra note 16; Weisslitz, supra note 7.

${ }^{78}$ See Anne Duval, supra note 16.

${ }^{79}$ Hunter et al, supra note 14, at 664.

${ }^{80}$ Peter Singer, (2002). One World, 33-34 (London: Yale University Press), Edward A. Page, supra note 30, at 168. 
Rather than stemming from disregard for the global environment, developing nations' reticence in assuming responsibility stems from priorities, ${ }^{81}$ and lack of financial resources associated with attaining the abatement standards central to many multilateral agreements. ${ }^{82}$ Such requests of the developing nations that MEAs should consider their special situations ${ }^{83}$ brought about the principle of 'common but differentiated responsibility' into the MEAs which has contributed to the success of the Montreal Regime. ${ }^{84}$ The contribution of this principle in the efforts to combat global ozone depletion and in the protection of the interests of developing countries is highlighted below.

\subsection{Mechanisms Devised by the Ozone Layer Regime}

There are multiple factors behind the success stories of the Montreal regime that can be transferred to other regimes. These factors include international scientific cooperation and consensus, an incremental policy process, the targets and timetables approach, involvement of multilateral institutions, and more effective manifestations of the common but differentiated responsibility principle. ${ }^{85}$ Above all, the meaning given to the principle of 'common but differentiated responsibility' is central for the inclusion of developing countries and for the success of the regime. ${ }^{86}$ In the context of the Montreal Protocol, one aspect of this principle is to allow developing countries to delay the implementation of control measures, ${ }^{87}$ while developed countries provide financial assistance and technology transfer mechanisms to developing countries. ${ }^{88}$

${ }^{81}$ Kilaparti Ramakrishna, (1992). 'Interest Articulation and Lawmaking in Global Warming Negotiations: Perspectives from Developing Countries', 2 Transnat'l L. \& Contemp. Probs. 153, at 168.

${ }^{82}$ Drumbl, Northern Economic Obligation, supra note 54, at 365.

${ }^{83} \mathrm{Id}$.

${ }^{84}$ Bankobeza, DR. Gilbert, Strengthening the Implimentation of Multilateral Environmental Agreements, United Nations Environment Programme Ozone Secretariat, Seventh International Conference on Environmental Compliance and Enforcement, at 253 - 258; Lauren Kelly, supra note 24, at 2.

${ }^{85}$ Laura Thoms, supra note 3 , at 805.

${ }^{86}$ Id. Common but differentiated responsibility is well defined as: "All States have common responsibilities to protect the environment and promote sustainable development, but because of different social, economic, and ecological situations, countries must shoulder different responsibilities." Hunter, supra note 14, at 402.

${ }^{87}$ Bankobeza, DR. Gilbert, supra note 84.

${ }^{88} \mathrm{Id}$. 


\subsubsection{More Flexible Freeze and Phase-out Schedules}

The Montreal Protocol regime recognized the special situation of developing countries in their pursuits to meet its basic domestic needs and their compliance was offered a grace period of ten years as long as it does not "exceed an annual calculated level of consumption of 0.3 kilograms per capita." 89 Hence, the most significant ODSs were scheduled for phase-out in 1996 in the developed countries but only in 2010 in developing countries, otherwise known as Article 5 Parties. ${ }^{90}$ In addition, Article 5 Parties were required to freeze the use of methyl bromide in 2002, leading to phase-out in 2015 and HCFCs in 2016 and phased out in 2040, which is at least ten years later than the timeline for the developed nations. ${ }^{91}$ With regard to the calculation of its baseline "...either the average of its annual calculated level of consumption for the period of 1995 to 1997 inclusive or a calculated level of consumption of 0.3 kilograms per capita, whichever is the lower" was considered. However, the baseline for developed countries was mostly the calculated level of consumption in $1986 .{ }^{92}$

The period of grace is intended to allow developing countries to provide for their basic domestic needs during the transition away from ODSs and to enable them learn from the experience gained in the developed countries in the course of implementing the Montreal Protocol regime. ${ }^{93}$ However, there were challenges in the implementation of the grace period. For instance, US farmers requested that "methyl bromine is necessary for them to compete with developing countries" and successfully lobbied for its continued use in the name of exemptions past the 2005 deadline. ${ }^{94}$ The other challenge was the critique that the grace period granted to developing countries in the production and use of ODSs while the consumption freezes in developed nations increases the traffic of illegal trade. ${ }^{95}$ Irrespective of such critics, however, developing nations have

${ }^{89}$ Montreal Protocol, supra note 19, article 5(1).

${ }^{90}$ Lauren Kelly, supra note 24, at 2.

${ }^{91}$ Hunter et al, supra note 14, at 594.

92 Ozone Secretariat UNEP, (2005). Production and Consumption of Ozone Depleting Substances under the Montreal Protocol 1986 - 2004, Third Edition, at 8, available at www.ozone.unep.org/Publications/Production_and_consumption2005.pdf/ lasted visited on September 13, 2011; see also Hunter et al, supra note 14, at 590-596. For some ODSs the baseline, however, for developed nations were 1989 and 1991. In such instance, the baseline will become 1998-2000 and 2015 for Article 5 Parties.

${ }^{93}$ Lauren Kelly, supra note 24, at 2.

94 Hunter, supra note 14, at 597.

${ }^{95}$ Ozone Action Newsletter, (2001). The Scope of the Problem: An Overview of Illegal ODS Trade, Illegal Trade in Ozone Depleting Substances: Is There a Hole in the Montreal Protocol?, at 4 www.unep.fr/ozonaction/.../3617-e- 
benefited from the flexible freeze and phase-out schedules that were designed in the ozone layer regime to the benefit of developing countries.

\subsubsection{Financial Assistance}

The Montreal Protocol's London Amendment in June 1990 created the Multilateral Fund for the Implementation of the Montreal Protocol. ${ }^{96}$ It has the general objective of helping developing countries to comply with their obligations under the Protocol to phase out the use of ODSs at an agreed schedule $^{97}$ and the fund finances activities mandated to decrease production and consumption of ODSs. ${ }^{98}$ In order to make financing available before the entry into force of the London Amendment, the parties also agreed to establish an Interim Fund, which became effective on January 1, 1991.99

The Fund was a financial mechanism which embodied the principle that countries have a common but differentiated responsibility to protect and manage the global commons. ${ }^{100}$ It is managed by an Executive Committee with an equal representation of seven industrialized and seven Article 5 Parties, which are elected annually by a meeting of the parties. ${ }^{101}$ Financial and technical assistance is provided in the form of grants or concessional loans and is delivered through its implementing agencies. ${ }^{102}$

The Fund, which is replenished seven times every three years, receives monetary contributions from industrialized member nations (Non-Article 5 Parties) based upon the United Nations Scale of Assessment. ${ }^{103}$ It finances

oansupplement6IllegalTrade.pdf/ last visited on July 10, 2012; See also Lauren Kelly, supra note 24, at 23.

${ }^{96}$ See, The Multilateral Fund for the Montreal Protocol, available at http://www.multilateralfund.org/default.aspx/ last visited on September 9, 2011.

${ }^{97}$ Multilateral Fund Secretariat, (2002). Multilateral Fund for the Implementation of the Montreal Protocol, Policies, Procedures, Guidelines and Criteria, at 2, $\mathrm{UNEP} / \mathrm{OzL}$.Pro/2/3/Decision II/8. Available at http://www.unmfs.org/PDF/Policy37.pdf/ lasted visited on August 18, 2009.

${ }^{98}$ See, The Multilateral Fund, supra note 96.

${ }^{99}$ Id. The Multilateral Fund becomes fully operational only in 1993.

${ }^{100} I d$.

${ }^{101} \mathrm{Id}$

${ }^{102}$ See, James Andrew Bove, supra note 68; see also Multilateral Fund for the Implementation of the Montreal Protocol, Implementing Agencies, at $<$ http://www.multilateralfund.org/aboutMLF/default.aspx $>$. Last visited on June 10, 2012.

${ }^{103}$ Adjustments and Amendment to the Montreal Protocol on Substances that Deplete the Ozone Layer, U.N. Environment Program, (1990). U.N. Doc. 
activities like project preparation, training and capacity building programs, technical assistance, information exchange, demonstration projects, institutional strengthening, small investment projects, and industrial conversion. ${ }^{104} \mathrm{It}$, however, funds only the additional (the so-called 'incremental') ${ }^{105}$ costs incurred in converting to non-ODS technologies. ${ }^{106}$.

The Fund has been an integral part of the success of the Montreal Protocol. The establishment of the Fund in 1990 persuaded many developing countries, like China and India, to join the combat against ozone depletion. ${ }^{107}$ Up to 2008, the Executive Committee has approved over USD 2.6 billion to finance over 6,700 projects and activities in 145 countries. ${ }^{108}$ The implementation of these projects "will result in the phase-out of the consumption of more than 254,687 ODP tons and the production of about 176,439 ODP tons of ODSs". 109

Other Fund achievements include the approval of 143 country programs in Article 5 countries and the establishment of ozone offices in 143 Article 5

UNEP/Oz.L.Pro2/3, 30 I.L.M. 537; agreed by the Second Meeting of the Parties, [hereafter London Amendment] article 10(6).

104 See, James Andrew Bove, supra note 68; see also Executive Committee of the Multilateral Fund for the Implementation of the Montreal Protocol, Report of the Tenth Meeting of the Executive Committee of the Multilateral Fund for the Implementation of the Montreal Protocol, (1993). U.N. Environment Program, Annex I, at 10, U.N. Doc. UNEP/OzL.Pro/ExCom/10/40 .

${ }^{105}$ U.N. Environment Programme, Executive Committee of the Multilateral Fund for the Implementation of the Montreal Protocol, Report of the Twenty-Fourth Meeting of the Executive Committee of the Multilateral Fund for the Implementation of the Montreal Protocol, (1998). Annex I, at 4, U.N. Doc. UNEP/OzL.Pro/ExCom/24/27; See also James Andrew Bove, supra note 68.

${ }^{106}$ See, The Multilateral Fund, supra note 96.

107 See, Lauren Kelly, supra note 24, at 3. China and India successfully lobbied the addition of US $\$ 80$ million to the already allotted US $\$ 160$ million of the Fund as a precondition to join the regime.

${ }^{108}$ See, The Multilateral Fund, supra note 96. In China alone, the largest consumer and producer of ODSs among Article 5 Parties, under the Multilateral Fund, as of November 1995, 155 projects had been implemented and "of the 459,910 ODP tonnes to be eliminated once all these projects have been implemented, a total of 448,808 ODP tonnes had already been phased out by the end of December 2010". James Shepherd, (2007). The Future of Technology Transfer Under Multilateral Environmental Agreements, ELR, News and Analysis, reprinted by, Environmental Law Institute ${ }^{\circ}$, Washington, DC, 37 ELR, 10547-10561

${ }^{109} \mathrm{Id}$ 
Parties. ${ }^{110}$ Ethiopia has benefited from the Fund, and so far out of the approved amount of USD 605,067 , USD 375,810 has been disbursed to Ethiopia. ${ }^{111}$ Therefore, the Multilateral Fund has contributed to the phase-out of ODSs by encouraging the participation of developing countries and sponsoring domestic capacity-building exercises and by creating the sense of cooperation and commitment amongst the parties. ${ }^{112}$

\subsubsection{Technology Transfer}

Due to the lack of a strong clause in the original Montreal Protocol, ${ }^{113}$ Article 5 Parties, led by India, China and Brazil requested technology transfer schemes to be "available on a preferential and non-commercial basis" and further requested developed nations to go to the extent of changing their laws for its effectiveness. ${ }^{114}$ Developed nations, however, objected that they could not compel their industries to transfer technology on a non-commercial basis, and proposed that technology will only be transferred to countries that respect intellectual property rights, and through joint ventures and licensing arrangements. ${ }^{115}$ In the end, the London Amendment was a compromise of these two conflicting interests, ${ }^{116}$ and is considered as "the first treaty where developed countries accepted their responsibility for protecting the environment by assisting developing countries with technology transfers". 117

Although transfer of technology is a very complex process surrounded by many challenges, UNEP and UNDP have accomplished different projects in the implementation of the technology transfer schemes in the ozone regime. ${ }^{118}$ This

${ }^{110} I d$.

111 The Multilateral Fund Secretariat, Multilateral Fund for the Implementation of the Montreal protocol: Country Programme and Compliance Summary Sheets (As at July 2007), at 88.

${ }^{112} \mathrm{Id}$.

113 It only set that "The Parties shall...taking into account in particular the needs of developing countries, co-operate in promoting technical assistance..." and parties may "...request to the Secretariat for technical assistance for the purposes of implementing or participating in the Protocol." Montreal Protocol, supra note 19, article 10.

114 Hunter et al, supra note 14, at 611 .

${ }^{115}$ Id.

${ }^{116}$ London Amendments, supra note 103, Article 10(A).

${ }^{117}$ Hunter et al, supra note 14, at 591.

118 David Strelneck and Peter Linquiti, Environmental Technology Transfer to Developing Countries: Practical Lessons Learned During Implementation of the Montreal Protocol, (ICF Consulting Working Paper, Presented at the 17th Annual 
is especially true for the transformation of Chinese and Indian refrigerator, foam and air conditioning industries. ${ }^{119}$ One of the major successes of the Montreal Protocol is the transfer of technology to the Indian refrigeration industry, under the auspices of the Ecofrig Project. ${ }^{120}$ With the collaboration of German, Indian, and Swiss governments, the Ecofrig Project helped Indian companies to acquire the necessary knowledge and replace the CFCs that were used in its refrigeration industry with new non-CFC equipment. ${ }^{121}$

Hence, effective implementation of the technology transfer regime helped developing nations to comply with their commitment without much cost and allowed developed nations to achieve their common goal. These are some of the factors that have had direct impact on the inclusion of developing nations thereby contributing to the success of the ozone regime. Other factors such as the comparative advantage of US companies over others and the green business movements by private actors have contributed to the success of the ozone regime.

\subsection{Differences and Similarities between the Ozone Layer and Climate Change Regimes}

Stratospheric ozone depletion and climate change are the two most significant environmental challenges facing the world today. ${ }^{122}$ In spite of the ambitious global plan to reverse these environmental harms, the degree of government cooperation and the fundamental change that is required in human economic and

Research Conference of the Association for Public Policy and Management), at 4-6. available at $<w w w . i c f c o n s u l t i n g . c o m>$. Last visited on August 18, 2009; see also Gilbert M. Bankobeza, (2005). Ozone Protection: The International Legal Regime, 208, at 240-242.

119 O. Yoshida, (2001). The International Legal Regime for the Protection of the Stratospheric Ozone Layer, 6 Int'l L. Japanese Persp. 273. This includes the efforts taken to replace Chinese CFC-based foam-blowing machinery with new non-CFC equipment and projects to initiate the recovery, recycling, and reuse of CFCs during equipment servicing in the refrigeration and air conditioning service industries have been undertaken. See David Strelneck, supra note 118.

${ }^{120}$ See, James Shepherd, supra note 108.

${ }^{121}$ See, Id; and International Energy Agency, (2001). Technology Without Borders 11, at 22 .

${ }^{122}$ Cumberlege, supra note 6, at 303 . The fact that ozone layer will not return to its pre 1980s status before 2050 and the need for continuous compliance to the regime makes stratospheric ozone depletion a significant environmental concern even today. 
social behavior render ozone depletion addressable while climate change remains contentious. ${ }^{123}$

One of the common features of the two issues is the need for multilateral action to protect global commons. ${ }^{124}$ Even if the contribution of developing nations is minimal in both cases as the source of the problems, the regime will not succeed without meaningful participation of developing nations. ${ }^{125}$ Consequently, the inclusion of developing nations for effective international ozone depletion or climate change regulation is not an option. ${ }^{126}$

The other similar characteristic is the unequal contribution by developed and developing countries, which further complicates the global response. ${ }^{127}$ Hence, both present contentious issues of international (intra-generational) equity in that developed countries are the primary contributors to both environmental problems and therefore, should assume predominant roles in mitigation efforts. ${ }^{128}$ This, then, requires a meaningful and advanced participation of developed nations not only in mitigating the direct cause of these environmental problems but also providing financial assistance and technology transfer to developing nations in their pursuits to curb the common problem. ${ }^{129}$ Likewise, the economic ability of developing nations to effectively deal with these environmental problems and their current priority in providing basic means to citizens are common concerns of the regimes. ${ }^{130}$ As a result, developing nations pledge to assume lower or no binding responsibilities in mitigating the problems. ${ }^{131}$

It is to be noted that both environmental concerns involve the 'tragedy of the commons' where some states 'free ride' on the efforts of others by benefiting

\footnotetext{
${ }^{123}$ Cass R. Sunstein, supra note 28, at 2.

${ }^{124}$ Id, at 2; Jasmine Abdel-khalik, (2001). Prescriptive Treaties in Global Warming: Applying the Factors Leading to the Montreal Protocol, 22 Michigan Journal of International Law 489, at 514.

${ }^{125}$ Jasmine, Ibid, at 514; Hunter, supra note 14, at 664.

${ }^{126}$ Laura Thoms, supra note 3, at 799.

${ }^{127}$ Michael McKenzie, supra note 70, at 681.

${ }^{128}$ Cumberlege, supra note 6 , at 303 . Added is the intergenerational equity raised on both problems due to the long life span of the anthropogenic emission and their long effect. Hence, the future generation is expected to suffer much unless the current generation makes meaningful sacrifice for the benefit of the future generation. See Cass R. Sunstein, supra note 28, at 3.

${ }^{129}$ See, John Ntambirweki, supra note 65.

${ }^{130} \mathrm{See}, \mathrm{Id}$.

${ }^{131} \mathrm{Id}$, at 912
} 
from the significant costs borne by parties that comply with their obligations. ${ }^{132}$ Hence, any solution to these problems has to deal with the tendency of states to 'free ride' on the benefits accrued from mitigating actions of other states, and the solutions are also accompanied by the uncertainty whether other parties to a binding agreement will actually observe their commitments. ${ }^{133}$

Lack of practical alternatives to the various uses of ODSs and energy consumption during the early period of negotiations were challenges which, inter alia, necessitated the participation of corporations. Ultimately, scientific and technological advances have shown viable alternatives to replace coal and fossil fuels while still producing the requisite amount of energy. ${ }^{134}$ Although these technologies are environmentally friendly and economically feasible, the ultimate objectives of scaling them up, bringing them to the market and replacing the existing coal and fossil fuel energy involve further tasks and sustained testing. ${ }^{135}$

In spite of the differences, the global responses to the problems of ozone depletion and climate change problems also share some common features, which include: enhanced scientific cooperation and involvement in the negotiations, an incremental approach and the creation of targets and timetables, the principle of "common but differentiated responsibility", and multiple mechanisms to encourage and assist the participation of developing countries. ${ }^{136}$

${ }^{132}$ Cumberlege, supra note 6, at 303; see also James K. Sebenius, (1991). 'Designing Negotiations Toward a New Regime: The Case of Global Warming', 15 Int'l Security 110, at 119; John Vogler, Studying the global commons: governance without politics? In Peter Dauvergne, edr. (2005). Handbook of Global Environmental Politics, University of British Columbia, Canada, at 51-55 (Edward Elgar Cheltenham, UK • Northampton, MA, USA,).

${ }^{133}$ Laura Thoms, supra note 3 , at 799.

134 Jasmine, supra note 124, at 516-518. Suggestion are coming to the utilization of natural gas, electricity or hydrogen facility, biomass as a fuel source with subsurface sequestration, wind turbine technology, and new technologies to reduce automobile emission, and other green energy sources like solar. See also Joshua P. Fershee, (2010). 'Struggling Past Oil: The Infrastructure Impediments to Adopting NextGeneration Transportation Fuel Sources', 40 Cumb. L. Rev. 87; Mark E. Rosen, (2010). 'Energy Independence And Climate Change: The Economic And National Security Consequences Of Failing To Act', 44 U. Rich. L. Rev. 977.

${ }^{135}$ Jasmine, supra note 124 , at 518.

${ }^{136}$ Laura Thoms, supra note 3, at 817; see also Jorgen Wettestad, (1999). Designing Effective Environmental Regimes: The Key Conditions, 221-23; Ved P. Nanda \& George Pring, (2003). International Environmental Law for the 21st Century, at 29394; and Cumberlege, supra note 6, at 317-18. 
Yet, there are important differences among the two that, partly, contribute to the different success stories of the regimes.

Climate change is a much more difficult phenomenon to regulate because it is more scientifically complex than ozone depletion and is still characterized by high scientific uncertainty and sharp asymmetrical vulnerabilities. ${ }^{137}$ This plagues global efforts to reach consensus on lasting climate change alleviation. ${ }^{138}$ There is more convincing scientific evidence about climate change today than during the Kyoto negotiations. However, some scientific uncertainty still remains to show the causation between emissions and large visible environmental problems. ${ }^{139}$ Scientific uncertainty and causation had also delayed the ozone regime until overwhelming evidence, e.g. ozone hole, was found in 1985 to show stronger causation between CFCs/ODS and ozone depletion. ${ }^{140}$ In spite of the delay in levels of certainty regarding the causation in global warming, many scientific data and reports, including that of IPCC, are now strongly filling the gap in evidence and they seem to nearly irrefutable, ${ }^{141}$ or are becoming a "smoking gun," ${ }^{42}$ soon to be followed by a growing consensus on the need to act swiftly and strongly. ${ }^{143}$

The other, and perhaps the most important difference, is the fact that climate change mitigation affects core global economic activity which inherently involves issues of competition between nations. ${ }^{144}$ Specifically, climate change alleviation implicates multiple sectors of the global economy, particularly those that have, throughout modern history, served as the backbone to industrial growth and development, making the cost of mitigation tough to bear. ${ }^{145}$ The use of ODSs was confined to a relatively small amount of products, like refrigerators, fire extinguishers, foam, etc. whereas greenhouse gas emissions arise from nearly all areas of modern life. As a result, any approach to climate change has wider and more significant economic implications than the global efforts to combat ozone depletion, both for developed and developing nations. ${ }^{146}$

\footnotetext{
${ }^{137}$ Laura Thoms, supra note 3, at 823; see also Cass R. Sunstein, supra note 28, at 2-4, 45; Cumberelege, supra note 6, at 316.

${ }^{138}$ Laura Thoms, supra note 3 , at 824.

${ }^{139}$ Cumberlege, supra note 6 , at 316.

140 Jasmine, supra note 124, at 512.

141 See, Id, at 513.

142 See, Susskind, supra note 2, at 66.

${ }^{143}$ A Warming Warning, (2001). The Washington Post, Jan. 28, at B6; Jasmine, supra note 124 , at 513

${ }^{144}$ Cass R. Sunstein, supra note 28, at 11.

${ }^{145}$ Cumberlege, supra note 6, at 317.

${ }^{146}$ Green, supra note 5, at 282-283.
} 
Hence, mitigating the effects of climate change is accompanied by "unprecedented challenges, because it can only be achieved through extraordinary changes in the production and consumption of energy, thus affecting virtually all areas of economic activity." "147

A related aspect is the imbalance between "total costs of greenhouse-gasemission abatement and total benefits of avoided undesirable consequences of global warming." ${ }^{148}$ In making the choice between continuing GHG emission and abating emission, countries will obviously choose to do that which presents a higher payoff. ${ }^{149}$ It is worth of note that developing nations that do not contribute much for the problem will be affected severely by the consequences of climate change more than the developed nations. ${ }^{150}$ Conversely, developed nations that caused the depletion of the ozone layer were the most to be affected by its effects. ${ }^{151}$ Hence, the incentive and cost-benefit analysis of combating climate change is quite different from that of ozone depletion even among developed nations. ${ }^{152}$

${ }^{147}$ See Rudiger Wolfrum \& Jurgen Friedrich, (2006). The Framework Convention on Climate Change and the Kyoto Protocol, in Ensuring Compliance with Multilateral Environmental Agreements: A Dialogue between Practitioners and Academia, 53 (Ulrich Beyerlin, Peter-Tobias Stoll \& Rudiger Wolfrum eds,).

${ }^{148}$ Cumberlege, supra note 6, at 323; Christoph Bohringer \& Michael Finus, (2005). The Kyoto Protocol: Success of Failure?, in Climate-change Policy, 254, at 258 (Dieter Helm ed,).

${ }^{149} \mathrm{Id}$, at 324.

${ }^{150}$ For instance, some estimates that climate change will reduce the GDP of developing nations by $5 \%$ or more while it only reduces GDP of the developed by $1 \%$ or $2 \%$. The Maldives, for example, which consists of 1200 islands lying, on average, two metres above sea-level, is an example of a country that could cease to exist in a hundred years due to rising sea levels. IPCC, Fourth Assessment Report, supra note 31; Cass R. Sunstein, supra note 28, at 32.

${ }^{151}$ Assessments show that though the effects of ozone depletion are spread across nation of the world, its effects, like increase in cancer case, eye cataract, defects in immune system, is much more severe in the developed north as the depletion is severe around the Northern Hemisphere, like Europe, Russia, USA, and remote South. As a result, developed nations were under the pressure from their own citizens, who are immediate victims of the problem resulted from their own activity. It has also been claimed that the light skin color of the North made them vulnerable to skin cancer, one of the adverse causes of ozone depletions. Hunter, supra note 14, at 567, 570571; Cass R. Sunstein, supra note 28, at 21.

152 Robert N. Stavins, (1997). 'Policy Instruments for Climate Change: How Can National Governments Address a Global Problem?' Univ. of Chi. Legal F. 298, at 298; Id at 30-34, and 48-49. US, for instance, is expected to incur a cost of US4 325 billion for a benefit amounting only US\$ 12 billion to comply for Kyoto with a 
In spite of the underlying differences between the two problems, lessons drawn from the ozone regime can be adapted and applied towards future achievements and successes in the climate change regime. ${ }^{153}$ We cannot, however, address the challenges in the climate change regime through a perfunctory application of the schemes used under the ozone regime, but by means of a tailored and pragmatic approach that considers the special circumstances of climate change problems discussed above.

\section{Lessons for the Climate Change Regime}

According to Thoms, the inherent nature of the climate change problem, including factors that are beyond the control of international negotiators "has weakened domestic support, strengthened opposition from industry and developing nations, turned the United States into a reluctant participant in international negotiations, and undermined negotiators' ability to implement trade restrictions." " negotiators, some even consider the emission reduction scheme reached so far as a remarkable success. ${ }^{155}$ Nonetheless, as highlighted below, the climate change regime can benefit from several factors that contributed to the success of the ozone regime with a view to accommodating and enhancing the meaningful participation of developing nations in the global pursuits to address the problem of climate change. ${ }^{156}$

negative net benefit. It is noted as well that there are some developed nations, such as Canada and Russia, who are net beneficiary of the climate change due to the effects of increased temperatures and precipitation on agricultural production. Scott Berrett describes that "The USA failed to participate (at least in part) because the costs of participation were high. Other countries agreed to participate (at least in part) because the costs to them of participating were low (as is true for some EU states), zero (as is true for all non-Annex I states) or even negative (as is true for the states given 'hot air' allowances). The Annex I countries likely to have the hardest time complying (Canada and Japan) agreed to participate only on the condition that their initial reduction obligations be diluted." Cumberlege, supra note 6, at 327, quoting, Scott Barrett, (2003). Environment and Statecraft: The Strategy of Environmental Treaty-making, at 295.

${ }^{153}$ Laura Thoms, supra note 3, at 796.

${ }^{154} \mathrm{Id}$, at $843-844$

${ }^{155} \mathrm{Id}$.

${ }^{156} \mathrm{Id}$, at 796 and 844. 


\subsection{Sequential Approach to Developing Nations}

One of the basic factors that contribute to the low-level of success of the climate change regime is the North-South dichotomy regarding 'who-first, when, and how much' in emission abating. Negotiators in the ozone regime solved this problem through mostly separate commitments of industrialized and developing nations with a sequential inclusion of parties. ${ }^{157}$ The more urgent issue of reaching binding controls on industrialized nations was resolved in the Montreal Protocol which also set the terms of future developing nations' participation (binding reductions with a ten-year implementation delay and the possibility of increased CFC production in the interim), followed by trade restrictions to assure compliance and enhance participation. ${ }^{158}$ The negotiators finally provided developing nations with the necessary incentives through a combination of trade restrictions and financial and technological transfers to ensure their participation in the ozone regime. ${ }^{159}$

Some urge that the 'inclusive' approach should be pursued in the climate change regime where developing nations are required to fully participate in the regime. ${ }^{160}$ Other writers, nonetheless, suggest that negotiators of climate change should adopt a sequential approach to the inclusion of industrialized and developing nations, for it is imperative to bind the most immediate source of the problem first - the industrialized nations - and then turn to the secondary issue of participation by developing nations. ${ }^{161}$ Otherwise, as has been witnessed in past negotiations, discussions may become bogged down and issues polarized. ${ }^{162}$ It is equally significant to resolve the reluctance of some industrialized nations in assuming responsibility under the pretext of equal participation by developing

${ }^{157} \mathrm{Id}$, at 838 .

${ }^{158} \mathrm{Id}$

${ }^{159}$ Wettestad, supra note 136 , at 143.

160 For instance, the US Senate, in the 1997 Byrd-Hagel Resolution, decided unanimously (95-0) for similar treatment of industrialized and developing countries in any climate change agreement and the existing short-term developing country's' participation through the CDM is short of the criteria required by the Byrd-Hagel Resolution. Stavins and Berrett, supra note 36, at 11-12; see also Steinar Andresen, (1998).

${ }^{161}$ Laura Thoms, supra note 3 , at 844.

162 For instance, the Byrd-Hagel resolution of US Senate comes before Kyoto negotiation affecting the interest and offers of negotiators to the protocol. Similarly, negotiating coalition strengthened with the formation of G-77 plus China that have a force to block the success of any agreement unless their interests are well considered. See Id, at 839-840 and 844; Peter Newell, (2000). Climate for Change, Non-State Actors and the Global Politics of the Greenhouse 9, at 13-18. 
nations by ensuring that developing nations would eventually join and agree to binding restrictions, which will allay the competitiveness concerns. ${ }^{163}$

Yet the existing flexible mechanisms devised under the Kyoto Protocol do not efficiently address the competing interests involved in the climate change regime nor do they effectively enable a sequential approach to state participation (mostly due to regulatory uncertainties). ${ }^{164}$ Hence, Thoms proposes that the flexibility mechanisms should be exclusive and only those developing nations that join the regime should benefit from these schemes. ${ }^{165}$

This does not, however, entirely relieve developing countries from responsibilities and commitments because the high and rapidly growing GHG emissions of developing nations, which is different in degree from the ozone regime, creates a challenge for strictly applying the sequential approach followed in the ozone regime. One way of overcoming this challenge is determining equitable allocation of commitments based on the Human Development Index (HDI) combined with historic GHG emissions, energy use increases needed to improve low HDI and associated human poverty indices, and the efficiency with which energy is used, instead of per capita emissions that dominate the current negotiation. ${ }^{166}$ Thus, the average of the present per

${ }^{163}$ Laura Thoms, supra note 3, at 845 . A very typical example is USA's position towards Kyoto Protocol..

${ }^{164}$ Of course, it provides automatic incentives for participation by some developing nations without direct financial input from parties Thus, at the Buenos Aires conference, Argentina became the first developing nation to assume binding targets and timetables for controlling emissions. Similarly, nations such as Honduras, Nicaragua, and Panama have joined the protocol to become "emissions entrepreneurs," profiting from the protocol's joint implementation and clean development mechanisms. Seth Dunn, (1998). Can the North and South Get in Step?, World Watch, Nov./Dec.; see also William Stevens, (1998). Deadline Set to Form Rules for Reducing Gas Emissions, Sun-Sentinel Fort Lauderdale, at 11; Laura Thoms, supra note 3 , at 845 .

${ }^{165}$ It is noted that "unless industrialized nations are certain that they will enter into effect and thereby induce involvement by developing nations, they will be reticent to agree to an approach that initially excludes the South. Similarly, unless developing nations are assured that the mechanisms will be implemented, they will not have the incentive to join the agreement." Laura Thoms, supra note 3, at 845 .

${ }^{166}$ It is much easier for developing countries to argue on the basis of per capita emission which is difficult to be accepted by the developed North. On a per capita basis, the historic emissions of the United States (about 1,100 tons per person) are greater than those of China (about 66 tons per person) and India (about 23 tons per person). Though the gross footprints of some of developing countries are growing rapidly, the United States (20.4 tons per person) emits far more per person than China (3.8) or India (1.2). The per capita allocation have negative consequence like discouraging 
capita emissions of each country and the potential capacity of a country for future per capita emissions can be considered. ${ }^{167}$

This scheme transforms the current North-South blocks into three groups of countries, i.e. high emitter developed countries, low emitter developing countries, and high emitter developing countries, and they can all benefit according to their own marginal cost of mitigating climate change. ${ }^{168}$ For instance, countries with low emission allocations would be forced to utilize the flexible mechanisms by carrying out development projects in countries with high emission entitlements while poor low carbon emitting countries would derive economic development benefits through CDM options. ${ }^{169}$ Likewise, middle nations, such as China and India, would still have the ability to grow, and could use the available emission credit to attract significant capital investment from developed countries. ${ }^{170}$

\subsection{Enhance Participation and Compliance}

The Kyoto Protocol has been ratified by 191 countries and seems to have maintained very high participation of nations. ${ }^{171}$ Yet, the production of GHGs is

developed nations to join the regime and invest on climate change mitigation and adaptation, and will adversely affect developing yet high per capital emitter nations. See UNDP, Human Development Report for 2007/2008, supra note 57, at 40-41, at 229-242, and 355-372; see also Albert Mumma and David Hodas, (2008). Designing A Global Post-Kyoto Climate Change Protocol That Advances Human Development, 20 Georgetown International Environmental Law Review 619, at 638642; see also Eric A. Posner and Cass R. Sunstein, (2009). Should Greenhouse Gas Permits Be Allocated On A Per Capita Basis? 97 California Law Review 51.

${ }^{167}$ Mumma and Hodas, supra note 166, at 640.

${ }^{168}$ The three groups of nations are countries with (1) historically low responsibility and low potential for future GHG emissions that would be entitled to the highest allocations of emissions (e.g. most African countries, small economies in Asia, and many of the small island states); (2) historically high responsibility for emissions and a high potential for future emissions would be allocated the lowest emissions entitlements (e.g. Annex I countries); and lastly (3) historically low responsibility for GHG emissions but high potential for future GHG emissions will be allocated with moderate emission entitlements (e.g. newly industrializing countries of China, India, Brazil, Mexico, South Africa, etc). See Id, at 640-642.

${ }^{169} I d$.

${ }^{170} \mathrm{Id}$.

${ }^{171}$ Currently, there are 193 Parties (192 States and EU) to the Kyoto Protocol to the UNFCCC. The Protocol entered in force on 16 February 2005. http://unfccc.int/kyoto_protocol/status_of_ratification/items/2613.php [last visited on August 27, 2011.] 
still increasing owing to factors like the withdrawal of major emitters, e.g. USA, from assuming any reduction commitment, failure of Kyoto signatory states from meeting their abatement commitment, and the exclusion of some major developing countries from the Kyoto commitment. ${ }^{172}$

Central to the problem is the meaning given and the actions that follow the principle of "common but differentiated responsibilities" since Kyoto was ratified. ${ }^{173}$ Developing nations are asserting that all major GHG-emitting nations have a duty to protect and take preventive or corrective action because they caused the degradation, benefited from past pollution, and currently possess technological and financial advantages to address the problem. ${ }^{174}$ Some developed countries, like the US, however, urge that all major GHG emitters, like China, India and Brazil should assume commitments. ${ }^{175}$

Parties to the Montreal Protocol negotiating table overcame the North-South division by including the common but differentiated responsibility principle based on which all parties assume responsibility but developed nations incur more (differentiated) obligations. ${ }^{176}$ Accordingly, developing nations were allowed to delay the freeze and phase-out of ODSs for ten years, and the Montreal Protocol established and successfully implemented financial assistance and technology transfer schemes. ${ }^{177}$ The inclusion of such provisions was "an essential element of the strong consensus behind the Montreal Protocol" and forced China, India and Brazil to join the regime. ${ }^{178}$

Theoretically, the climate change regime gives due recognition to the principle of common but differentiated responsibility same as that of the ozone regime. ${ }^{179}$ First, the UNFCCC and subsequent negotiations provide a mechanism for financial assistance and transfer of environmentally sound

172 See, for example, Mumma and Honda, supra note 166, at 623; Andrew Schatz, supra note 54, at 533; and Cumberlege, supra note 6, at 320-321.

${ }^{173}$ Lisa Schenck, supra note 42, at 367.

${ }^{174} \mathrm{Id}$.

${ }^{175}$ See Press Release, The White House, President Bush Discusses Global Climate Change, June 11, 2001, available at http://georgewbushwhitehouse.archives.gov/news/releases/2001/06/20010611-2.html last visited on July 10, 2012.

${ }^{176}$ See generally, for example, Weisslitz, supra note 7 where he argues that developing nations are proportionally treated in Montreal but not in Kyoto.

${ }^{177}$ Montreal Protocol, supra note 19, art. 5, P 1; see also Laura Thoms, supra note 3, at 811-12.

${ }^{178}$ Laura Thoms, supra note 6, at 811-12; see also David Hurlbut, supra note 68, at 352.; Wettestad, supra note 136, at 159.

${ }^{179}$ Wettestad, supra note 136, at 231. 
technologies to developing nations. ${ }^{180}$ Moreover, the Kyoto Protocol excludes developing nations from any binding emission reduction and even creates the $\mathrm{CDM}$ that will assist developing nations in meeting the cost of adaptation. ${ }^{181}$ Yet all these incentives are too little to attract meaningful participation of developing nations. ${ }^{182}$ As a result, many writers agree that Kyoto's commitments are "too little, too fast" or insufficient to avert the urgent problem, and insist on developing nations to play a more significant role over time. ${ }^{183}$

To secure meaningful participation of developing nations, additional incentives are recommended by different scholars. Stewart and Wiener recommended (1) a streamlined $\mathrm{CDM}^{184}$ (2) voluntary participation in emissions trading without emission quotas; (3) mechanisms for voluntary accession to the emissions quota system; and (4) automatic graduation to the quota system given particular per capita incomes having been reached, or an income threshold above which nations must take on emission commitments. ${ }^{185}$ Similarly, requiring them to participate in the financing of research and development activities (perhaps based on the UN scale of assessments) and to be

180 Press Release, (2009) Financial Support to Developing Countries for Climate Change: Is the EU Meeting its Previous Commitments? BRUSSELS/LONDON, 6 April 2009, see also Laura Thoms, supra note 3, at 819-820;

${ }^{181} \mathrm{Id}$

${ }^{182}$ Laura Thoms, supra note 3, at 812.

${ }^{183}$ Stavins and Berrett, supra note 36 , at 8 .

184 This includes providing incentives for equitable geographical distribution and meaningful participation of developing countries, improving standards and speeding up paper works for project approval, ensuring continuity of projects post 2012, excluding certain types of projects according to their impacts on sustainable development, continuous monitoring and evaluating of project's contribution to sustainable development, an improved system of "continuous performance monitoring" for the third party certifiers that assess requests for registration and issuance, establishing new procedures for stakeholders to appeal against decisions and the like. See Harro van Asselt and Joyeeta Gupta, supra note 7, at 364-370; see also James Murray, (23 Dec 2009). Business Green, http://www.businessgreen.com/business-green/news/2255410/copenhagen-greenlights-plan/ last visited on July 10, 2012.

${ }^{185}$ Stavins and Berrett, supra note 36, at 8, mentioning Stewart, Richard B. and Jonathan B. Wiener, (2001). "Reconstructing Climate Policy: The Paths Ahead." Policy Matters, 01-23. Washington, DC: AEI-Brookings Joint Center for Regulatory Studies,; see also John Copeland Nagle, (2011). HOW MUCH SHOULD CHINA POLLUTE? From the 2011 Vermont Journal of Environmental Law Symposium: "China's Environmental Governance: Global Challenges and Comparative Solutions", 12 Vt. J. Envtl. L. 591. 
bound by some technology standards (where the diffusion of these technologies would be financed by industrialized countries) are forwarded. ${ }^{186}$ In addition, the fact that any future negotiated outcomes are perceived as being fair to all parties serves as a self-incentive mechanism. ${ }^{187}$

On the other hand, many ratifying Annex-I nations, including Canada, Japan and the European Union, are skeptical about meeting their commitment in the first reporting years. ${ }^{188}$ Different factors contribute to this, including the lack of accurate emission baselines, unequal advantages of nations when 1990 is taken as a baseline and emission leakage. ${ }^{189}$ With regard to unequal advantages, countries like Russia whose emission is reduced since 1990 benefit thereof while others such as the US whose emission increased in the past decades are at a disadvantage.

Yet, the atmosphere is a global commons that the world community should protect collectively thereby avoiding the 'tragedy of the commons'. ${ }^{190}$ In the course of struggling to overcome a tragic outcome, equity issues, like free riding and the inequitable distribution of cost and benefits of collective action, pose difficulties for numerous nations. ${ }^{191}$ Hence, the existence of a strong legal regime (that brings all nations towards collective actions driven by gains and

${ }^{186}$ Stavins and Berrett, supra note 36, at 9. These enable developing nations to benefit from innovations and their industries to look for options in the future for they will not keep on emitting GHGs and becoming energy inefficient.

${ }^{187}$ See, Id, at 16.

${ }^{188}$ John Browne, (July/August 2004), Beyond Kyoto, Foreign Affairs 20,; Lisa Schenck, supra note 42, at 333.

${ }^{189}$ Lisa Schenck, supra note 42, at 333-334; see also Greg Kahn, Note, (2003). The Fate of the Kyoto Protocol Under the Bush Administration, 21 Berkeley J. Int'l L. 548, at 556; See Scott Barrett, (2005). Environment and Statecraft: The Strategy of Environmental Treaty-Making 382. Emission leakage is defined as "a phenomenon which occurs when businesses move their operations and accompanying emissions to unregulated countries to avoid the expenses of obtaining emission-reduction technology".

${ }^{190}$ See Garrett Hardin, (1968) The Tragedy of the Commons, Science, New Series, Vol. 162, No. 3859 (Dec. 13, 1968), pp. 1243-1248; Mancur Olson, (1965) The Logic of Collective Action: Public Goods and the Theory of Groups; Todd Sandler, (2004) Global Collective Action 11; Id, at 335-336.

${ }^{191}$ Free-riding occurs when some parties bear the costs of an action, while others, the free-riders, bear no burden, but still enjoy the benefits while inequitable distribution of cost and benefits arise where a large emitter reduces its emissions and incurs huge costs to the benefit of all other nations that will enjoy cleaner air. Lisa Schenck, supra note 42 , at 335-337. 
demonstrable net benefits, and perceived equitable apportionment of burdens) is indispensable. $^{192}$

To combat the problem of free-riding that plagues efforts to address this global concern, positive incentives for participation and compliance should be accompanied by credible and sufficiently severe disincentives. ${ }^{193}$ Hence, reciprocity or reciprocal measures, financial penalties and self-punishment and trade restriction that contributed to the success of the ozone regime could be adopted. ${ }^{194}$ The climate regime, however, does not include any of these trade measures that have partly contributed for the withdrawal of the US, failure of signatory states from meeting reduction commitments, failure of developing nations to assume any responsibility, and fueled arguments by industry blocking coalitions regarding anti-competitiveness and leakage. ${ }^{195}$

The fact that ODSs are man-made chemicals produced for industrial use while greenhouse gases are mostly industrial byproducts emitted as externalities of certain processes will complicate the latter and might conflict with the GATT. ${ }^{196}$ Consequently, redesigning the climate change regime to include trade restrictions and integrating the two competing realms of international trade and environmental law is necessary. ${ }^{197}$

192 See Daniel C. Esty \& Robert Mendelsohn, (1998). Moving from National to International Environmental Policy, 31 Pol'y Sci. 225, at 225.

${ }^{193}$ Stavins and Berrett, supra note 36, at 19; see also Mark E. Rosen, (2010). Energy Independence And Climate Change: The Economic And National Security Consequences Of Failing To Act, 44 U. Rich. L. Rev. 977.

${ }^{194} \mathrm{Id}$, at 20-22. Though there was not any practical trade restriction in ozone regime, the belief that trade would be restricted if countries failed to participate had promoted participation by providing market incentives to join and prevented nonparties from enjoying a competitive advantage and thus deterred leakage of CFC production facilities to non-parties. In addition, legal expert from the General Agreement on Tariffs and Trade ("GATT") secretariat affirmed that the trade restrictions under Montreal were permitted. Benedick, supra note 4, at 91;

${ }^{195}$ Laura Thoms, supra note 3, at 842 .

${ }^{196}$ Thus, climate change negotiators cannot follow the example of the ozone regime and place restrictions on the trading of the offending substance itself. Trade restrictions in the climate change regime will have to be placed primarily on products with production processes that emit greenhouse gases. This will not only be more difficult to monitor, but will also run into challenges under the World Trade Organization ("WTO") system, which tends to disfavor restrictions based on differences in production processes. Laura Thoms, supra note 3, at 843 mentioning David Victor, (2001). The Collapse of the Kyoto Protocol and the Struggle to Slow Global Warming, 42-43.

${ }^{197} \mathrm{Id}$, at 850 . 
The 'target and timetable' approach of the ozone regime, which is not well designed in the climate change regime, was very useful by sending a regulatory signal to CFC producers that investment in alternatives would be profitable. ${ }^{198}$ Instead of the short-sighted emissions target, future climate change negotiations should devise a long-term 'target and timetable' that will send an accurate message to industries. It is also important to provide industries with positive market incentives, disable their position by breaking up blocking coalitions, and delegitimize industry discourse for minimizing its pressure. ${ }^{199}$ Hence, governments are called upon to adequately respond to the rhetoric of industrial opposition in the climate regime with media campaigns regarding its science, adverse effects, economic competitiveness etc and device means to deal with free riders. Since lack of public concern can pressurize national governments from assuming responsibilities, norm-building efforts on the climate change issue must be developed. ${ }^{200}$

Norm-building activities, efforts toward industry fragmentation, ${ }^{201}$ and more state and federal climate change legislation could potentially result in U.S.

${ }^{198}$ Ozone regime clearly determined the phase-out schedule of ODS and producers know that these products will not survive in the market unless changed by its substitutes. This triggered CFC producing industries to get together in Washington only four months after the negotiation of Montreal to exchange information and invest on research and development for the invention of substitutes. Huge amount of many are invested for it by different companies to produce competitive or lowpriced CFC substitutes where DuPont alone invested \$30 million on research and development of CFC substitutes. Laura Thoms, supra note 3, at 810; Lisa Schenck, supra note 42; Benedick, supra note 4, at $6,47,53$; Wettestad, supra note 136 , at 132 and 137

${ }^{199}$ Laura Thoms, supra note 3, at 846. Unlike the ozone regime where industries like DuPunt were in the forefront for finding substitutes and mobilizing the public against $\mathrm{CFC}$, industrial rhetoric is going the opposite direction in the climate change regime. As Thoms observes, "industry climate change rhetoric has held a privileged position; themes of scientific uncertainty, economic disaster, and the threat of leakage and loss of competitive advantage to developing nations have pervaded public discourse and prevented U.S. action."

${ }^{200}$ It has been mentioned that British industries have started this task by singling out carbon dioxide emissions as the environmental "bad." Thus, Amerada Hess is selling zero carbon gasoline and the Carbon Trust has begun to develop zero carbon labels for industrial products, both with the intention of using the term "zero carbon" as a tool for gaining a marketing advantage. See Id, 851-52; last visited on August 27, 2010; Michael Grubb et al., (1999). The Kyoto Protocol: A Guide and Assessment 73 , at 258-60.

${ }^{201}$ Under the disguise of scientific uncertainty, economic disaster, and the threat of leakage and loss of competitive advantage to developing nations, industrial rhetoric 
accession to the climate change regime at least after 2012. ${ }^{202}$ However, looking at the urgency of action required of nations "successful global action will depend upon nations' successes in reaching definitional agreement than in crafting theoretical justifications for continued inaction." 203 Hence, emission reduction targets that are modest in the short-term but that steadily increase in stringency; mechanisms such as growth targets intended to increase developing country participation over time; and the use of market-based instruments are devices that can achieve, if implemented successfully, climate goals at relatively low cost. ${ }^{204}$

\subsection{Economic Assistance and Technology Transfer}

The issue of financial aid to developing countries for adaptation and mitigation of climate change problems were high since the UNFCCC negotiation. Hence, under the UNFCCC, developed nations agreed to make available "new and additional financial resources" to developing countries "on a grant or concessional basis" or through bilateral, regional and other multilateral channels which is operational through Global Environmental Facility (GEF). ${ }^{205}$

GEF, the financial administrator for climate change regime, operates under regular replenishments of its GEF Trust Fund by donor countries for three to four years. ${ }^{206}$ In addition to its Trust Fund, the GEF manages two special climate-related funds established under the Bonn/Marrakesh agreements: the Special Climate Change Fund (SCCF) ${ }^{207}$ and the Least Developed Countries

has got a privileged position. In addition, industrial blockings like coalitions of fossil fuel, utility, chemical, and automobile industries are formed to block international agreement. Laura Thoms, supra note 3, at 857-859.

${ }^{202} \mathrm{Id}$

${ }^{203}$ Lisa Schenck, supra note 42, at 368.

${ }^{204}$ Stavins and Berrett, supra note 36, at 26.

${ }^{205}$ UNFCCC, supra note 37, at Article 4(3), 11(1), 11(5) and 21(3). The Global Environment Facility (GEF) was set up in October 1991 to assist the protection of the global environment and to promote environmental sustainable development in the World Bank. Later on, in 1994, the GEF was restructured and moved out of the World Bank system to become a permanent and separate institution. http://www.thegef.org/gef/ last visited on Sept 12, 2011.

${ }^{206}$ See, $I d$, at 3 .

${ }^{207}$ The Special Climate Change Fund (SCCF) was created to help funding complementary to that GEF as part of its climate change adaptation and technology transfer areas. See Climate Change Secretariat, A Guide to the Climate Change Convention and its Kyoto Protocol, at 15 (2002), available at $\mathrm{http}$ //unfccc.int/resource/guideconvkp-p.pdf (preliminary version); see also Laura 
Fund (LDCF). ${ }^{208}$ The fourth and related fund attached to Kyoto under the UNFCCC is the Kyoto Protocol Adaptation Fund (KPAF) which is established under the Bonn/Marrakesh package to provide funding for concrete adaptation projects and programs in member developing countries from the 'share of proceeds' from CDM. ${ }^{209}$

To strengthen such funds, parties in the Bonn Declaration agreed "to contribute a total of USD 410 million per year by 2005 with this level to be reviewed again in 2008" and such fund to be directed towards the SCCF, the LDCF or the KPAF. ${ }^{210}$ But so far, as of January 2009, only USD 278 million has been given to the first two funds, i.e. SCCF and LDCF, by donor countries, but nothing to the KPAF due to the contentions over its administration. ${ }^{211}$ Moreover, though parties are duty bound to communicate such financial information related to implementation, lack of transparency, inadequacy of information and sometimes absence of the same and non-existence of official

Thoms, supra note 3, at 819-820; and Marc Pallemaerts and Jonathan Armstrong, (2009). Financial Support To Developing Countries For Climate Change Mitigation And Adaptation: Is The EU Meeting Its Commitments? Paper Presented at the International Conference on the External Dimension of the EU's Sustainable Development Strategy, 28 January 2009, Brussels, Institute for European Environmental Policy, at 3.

208 The Least Developed Countries Fund (LDCF) is specifically oriented towards helping the 48 Least Developed Countries (LDCs) establish and implement National Adaptation Programmes of Action (NAPAs) for a fight against the adverse effects of climate change. As of 2009, 15 donor countries have pledged over USD 172 million to the LDCF. See, Id, at 4.

${ }^{209}$ Kyoto Protocol, supra note 43, at article 12. Following verification of the results of CDM projects, the CDM Executive Board, governing body of the CDM, issues certified emission reductions (CERs) for each tonne of $\mathrm{CO}_{2}$ equivalent saved to the host country of the project. Out of the amount of certified emission reductions (CERs) generated by each CDM project, $98 \%$ are issued to the project sponsors and credited towards the fulfillment of the investor country's commitments while a "share of proceeds" amounting to 2\% of CERs is in the name of the KPAF and sold to fund adaptation projects in developing countries. As of today KPAF does not sponsor a single project. If the system works well the fund has the potential to collect USD 80-300 million from a 'share of proceeds' with in the period 20082012; See Harro van Asselt and Joyeeta Gupta, supra note7, at 345-370; Pallemaerts and Armstrong, supra note 207, at 4.

${ }^{210}$ Bonn Declaration, which has been signed by 21 nations, formed an essential element of the Bonn Agreement which paved the way for the successful conclusion of the negotiations on the 'Buenos Aires Plan of Action' at COP7 in Marrakesh a few months later.

${ }^{211}$ Pallemaerts and Armstrong, supra note 207, at 5 and 6. 
reports prevent many from fully evaluating the degree of attainment of the commitment included under the Bonn Declaration. ${ }^{212}$

The new Copenhagen Accord creates a "collective commitment" for developed countries to provide "new and additional resources ... approaching USD 30 billion" for the 2010-2012 period, ${ }^{213}$ and sets a longer-term collective 'goal' of mobilizing USD 100 billion per year by 2020 from all sources. ${ }^{214}$ It also established the Copenhagen Green Climate Fund "as an operating entity of the Convention's financial mechanism". ${ }^{215}$

Understanding that technology transfer is key for the regime, ${ }^{216}$ Articles 4.5 and 4.7 of the UNFCCC and 10(c) of the Kyoto Protocol call for developed nations to "promote, facilitate, and finance, as appropriate, the transfer of, or

${ }^{212}$ UNFCCC, COP5, 'Review of the Implementation of Commitments and of other Provisions of the Convention: UNFCCC guidelines on reporting and review', 16/02/2000, at 92; see also Article 12 of UNFCCC, supra note 37, and Article 7 of Kyoto Protocol, supra note 43; Id, at 15-16; see also Press Release, supra note 180.

213 Though data are not conclusive and times are left to meet the commitment, analysts are skeptical about the $\$ 10$ billion US contribution by the year 2010. For instance, out of $\$ 2.5$ billion expected share, President Barack Obama put out a budget request for only $\$ 1.4$ billion in international climate finance in February. In contrast, EU has pledged $\$ 3.3$ billion a year in quick-start funds, yet has promised to detail how it is adhering to its finance goal. However since, the administration of the fund, possible beneficiaries, conditions attached to the fund, respective obligation of developing nations are not yet settled, it is unlikely that the fund will attain its ends by the end of the first term. Confusion About Copenhagen Accord Casts Cloud Over UN Climate Treaty; Hopes for Trust-Building, Fast-Start Financing Dashed at Bonn by Stacy Feldman - Apr 12th, 2010.

${ }^{214}$ The sources are designated us public and private, bilateral and multilateral without specifying the shares of nations and its administration, but links this money to "meaningful mitigation actions and transparency on implementation." UN, however, projects $\$ 50-70 \mathrm{bn}$ a year to be invested immediately to help the poor countries adapt to extreme floods, droughts and heat-waves, with much more needed later. Copenhagen Accord, supra note 51, article 8; see also Daniel Bodansky, supra note 48 , at 237.

${ }^{215} \mathrm{Id}$, at article 10 .

${ }^{216}$ In the context of climate change, technology transfer is defined as the "flows of know-how, experience and equipment for mitigating and adapting to climate change amongst different stakeholders." Intergovernmental Panel on Climate Change, (2000). Summary For Policymakers, In IPCC Special Report: Methodological and Technological Issues In Technology Transfer 3; See also Alexander Adam, (2009). Technology Transfer to Combat Climate Change: Opportunities And Obligations Under Trips And Kyoto, 9 Journal of High Technology Law 1. 
access to," environmentally sound technologies. ${ }^{217}$ Furthermore, developing countries made it very clear in the Bali Action Plan of 2007 that technology transfer is very crucial for their inclusion in the emission reduction scheme. ${ }^{218}$ Accordingly, "developing countries agree to take measurable, reportable, and verifiable actions regarding emissions, on the condition that developed countries offer assistance to them with measurable, reportable, and verifiable financing, technology, and capacity building." 219 However, implementation is yet in its infant stage owing to different factors, including the potential conflict with international trade agreements. ${ }^{220}$ Although CDM is not a mechanism meant for technology transfer, developing countries can benefit from technology transfer as a side effect. ${ }^{221}$

The establishment of the Montreal Multilateral Fund, proportionate contribution by developed signatory states, technology transfer schemes implemented in most developing counties, like China, Brazil and India, and technical assistance delivered across the world in the ozone protection regime contributed to the rapid phase-out or reduction of many ODSs. ${ }^{222}$ The financial assistance and technology transfer scheme built into the climate regime, however, is far from being comprehensive, sufficient and attractive. ${ }^{223}$ Problems

${ }^{217}$ UNFCCC, supra note 37, article 4.5 and 4.7; Kyoto Protocol, supra note 43, at article $10(\mathrm{c})$.

218 United Nations Framework Convention on Climate Change, Conference of the Parties, Thirteenth Session, Bali, Indonesia, Dec. 3-15, 2007, Decision 1/CP.13: Bali Action Plan, (1)(b)(i)-(ii), U.N. Doc. FCCC/CP/2007/6/Add.1 (Mar. 14, 2008), available at http:// unfccc.int/resource/docs/2007/cop13/eng/06a01.pdf.

${ }^{219}$ Mei Gechlik, (2009). Making Transfer of Clean Technology Work: Lessons of the Clean Development Mechanism, 11 San Diego International Law Journal 227, at 229.

${ }^{220}$ See, for example, Cameron Hutchison, (2006). Does TRIPS Facilitate or Impede Climate Change Technology Transfer into Developing Countries? 3 University of Ottawa Law \& Technology Journal 517; see also Alexander Adam, supra note 216. Though TRIPS (Agreement on Trade Related Aspects of Intellectual Property Rights) will pose an enormous challenge to the transfer of EST in its full sense, scholars are finding lee ways to the challenge that encourages the two realms, environmental law and world trade to work together.

${ }^{221}$ Alexander Adam, supra note 216.

${ }^{222}$ See Cass R. Sunstein, (2008). Of Montreal And Kyoto: A Tale of Two Protocols, 38 Environmental Law Reporter News \& Analysis 10566, at 10568; Laura Thoms, supra note 3 , at 811 .

${ }^{223}$ See for example, Alexander Adam, supra note 216; K.Ravi Srinivas, (2009). Climate Change, Technology Transfer and Intellectual Property Rights, Research Information System Discussion Paper (RIS-DP \# 153), RIS, at 1. 
ranging from lack of commitment from donors, absence of comprehensive and effective institutions to administer climate change funds (many less effective funds are created compared to the single Montreal Multilateral Fund in the ozone regime), challenges posed by international trade, and lack of sufficient funds (which of course is much more than what was required by the ozone regime) prevent the mechanisms from lending much support to the climate change regime. ${ }^{224}$

\subsection{Enhance Political Commitment}

Given the degree of climate change problems, Anthony Giddens explains that, "at present we have no effective politics of climate change, especially at a national level [strong enough to resist the challenge from home] where much of the action must happen." 225 Similarly, Leo Brincat is skeptical about the existence of strong political will that would lead to a long lasting climate agreement in the near future. ${ }^{226}$ Only stronger and credible leadership and better communication, higher sense of social justice between all the parties concerned, and the integration of international commitments in the national legislation and effective implementation of the same would bring the long awaited change in the climate regime. ${ }^{227}$

${ }^{224}$ See for example Pallemaerts and Armstrong, supra note 207. For instance, nearly $\$ 18$ bn ( $£ 12.5$ bn) have been pledged in the last seven years by donors, "but less than \$0.9bn has been disbursed and long delays are plaguing many funds." Equitable distribution of the fund is the other problem where nearly one-third of the $\$ 760 \mathrm{~m}$ distributed in the last three years by GEF, has gone to China, India and Brazil and less than $\$ 100 \mathrm{~m}$ of this has gone to projects in the world's 49 poorest countries. John Vidal, (2009). Rich nations failing to meet climate aid pledges, the Guardian; available at http://www.guardian.co.uk/environment/2009/feb/20/climate-fundsdeveloping-nations/ last visited on August 26, 2011.

${ }^{225}$ Anthony Giddens, (2008). The Politics of Climate Change: National Responses to the Challenge of Global Warming, 5 (Policy Network Paper, UK, London). Available at http://www.policynetwork.net/uploadedFiles/Publications/Publications/. The_politics_of_climate_change_Anthony_Giddens\%282\%29.pdf/ last visited on January, 2010.

${ }^{226}$ Malta today, (2010). Without strong political commitment, fight against climate change can never be won, Leo Brincat, addressing in the meeting of the International ParliamentaryCommonwealth Conference with the theme 'The Challenges of Climate Change' in London, Charlot Zahra reporting, 17 February, 2010, available at http://www.maltatoday.com.mt/news/national/without-strong-political-commitmentfight-against-climate-change-can-never-be-won- $\%$ E2\%80\%93-br. Last visited on Sept 13, 2011.

${ }^{227} I d$ 
Various political analysts describe the existing political system and commitment too weak to bring the required change in the climate change regime, and suggest an increased role for the state. ${ }^{228}$ To achieve such a role, some prefer 'ensuring state' over 'enabling state'. ${ }^{229}$ The difference is that in the 'enabling state' system, state machineries are confined to stimulate others to act and let them go on with it while in the 'ensuring state' system, state machineries are expected to make sure that processes achieve certain defined outcomes, like emission reduction targets. ${ }^{230}$ It is also noted that good democratic leadership, motivated by 'deliberative democracy', should not be confined to policymaking alone but should also educate constituents about pressing issues such as climate change, that may not be apparent to them. ${ }^{231}$

Changes in national leadership also apathetically influences the degree of political commitment a nation assumes whereas the presence of continuous and uninterrupted domestic policies play a significant role for the effective realization of international obligations and long term objectives. ${ }^{232}$ This is because when obligations such as commitments towards climate change mitigation are particularly onerous, individual nations will adhere to them "only insofar as those nations perceive that positive net benefits...will be forthcoming." 233 For instance, fluctuation in the national policy of the US due to changes in political administration has prevented it from assuming a leadership role while it is the largest GHG emitter. ${ }^{234}$ Similarly, changes in government policies are affecting projects to be implemented in GHG emission mitigation in Germany and Canada. ${ }^{235}$

${ }^{228}$ Giddens, supra note 225 , at 9 and 16.

${ }^{229} \mathrm{Id}$, at 9.

${ }^{230} \mathrm{Id}$.

${ }^{231}$ David Held \& Angus Fane Hervey, (2009). Democracy, climate change and global governance: Democratic agency and the policy menu ahead, Policy Network Papers, UK, London, at 8. This is especially true for nations like USA that is facing firm, fixed and protective public opinion towards emission reduction. See Cass R. Sunstein, supra note 28, at 45-46.

${ }^{232}$ Lisa Schenck, supra note 42, at 332.

${ }^{233} \mathrm{Id}$, at 332 .

${ }^{234}$ For example, on April 21, 1993, President Clinton in introducing The Climate Change Action Plan stated "Today, I... announce our nation's commitment to reducing our emissions of greenhouse gases to their 1990 levels by the year 2000." White House, (1993), The Climate Change Action Plan: Executive Summary. However, his successor, President George Bush has notified the world that USA will not ratify the Kyoto Protocol.

${ }^{235}$ Lisa Schenck mentions Germany's recent action that exempted its coal industry from the European Union's carbon trading program that was designed to ensure Protocol 
Held and Hervey recommend multiple tasks both for individual states (developing and developed) and the international community to transform global climate change politics. ${ }^{236}$ They suggest that, individual states should garner their governance towards the broadening and deepening of the deliberative process, transform private preferences via a process of deliberation into positions that can withstand public scrutiny and test, continually involve citizens and civil society in the making and delivery of policy, create leadership that confronts narrow interests, and set out compelling scientific and economic case for action. ${ }^{237}$ They also underline that the international community should promote inclusive and broadly representative global decision-making channels, assist developing countries to access the necessary resources, capacity and technology for mitigation and adaptation, broaden the existing mandate of the GEF, and increase the status and responsibility of the UNEP by upgrading it onto a specialized UN agency. ${ }^{238}$

Some political leaders mention factors like scientific uncertainty, 'tragedy of the commons' or the free-rider problem as a pretext to veil the immense challenges they face from home, i.e. the public, large corporations and labor associations. ${ }^{239}$ Scientific uncertainty about climate change cannot, however, serve as a justification because the principle of precaution obliges them to act regardless of the degree of scientific certainty or estimated cost. ${ }^{240}$

Although the political commitments during the different stages of the negotiation and implementation of ozone depletion regime are very crucial,

compliance and Canada's action that transferred funding away from Protocol implementation projects to commuter tax credits support. Conversely, change in the political administration of the country, of course, helped Australia to ratify the Kyoto Protocol in 2007. Lisa Schenck, supra note 42, at 331-332

${ }^{236}$ Held and Hervey, supra note 231, at 2-17.

${ }^{237} \mathrm{Id}$, at 17.

${ }^{238} \mathrm{Id}$, at $15-17$.

239 Jason Scott Johnston, (2009). Problems of Equity and Efficiency in The Design of International Greenhouse Gas Cap-And-Trade Schemes, 33 Harvard Environmental Law Review, 423, at 426; Environment and Globalization, A Project of Levin Institute, at 32, available at http://www.globalization101.org. Accessed on January 10, 2010; But much positive effort is made by some nations, like USA and China to advocate and fund 'Green Job' by domestic frameworks. Regan, supra note 98, at 251, 271-72, 277-78.

${ }^{240}$ Lisa Schenck, supra note 42, at 366; see also Christopher D. Stone, (2001). Is there a Precautionary Principle? 31 ELR 10790. 
global and national politics was not a stiff challenge to the ozone regime. ${ }^{241}$ Acting even during scientific uncertainties was the center of the ozone regime as nations agreed to reduce production and consumption of ODS at a time when there were many unanswered questions in science, such as the uncertainty regarding the existence of substitutes for many uses of ODS. ${ }^{242}$

\section{Conclusion}

The high economic cost of reducing GHG emissions, few scientific uncertainties, lack of feasible and low-cost energy substitutes, and the allocation in share of responsibilities for developed and developing nations are the principal impediments against global consensus in the climate change regime. The fact that some developing nations have become high emitters as well as major economic competitors of developed nations has contributed to the problem. As a result, some developed nations like the US have failed to assume responsibility in the Kyoto Protocol claiming that high emitter developing nations like India, China and Brazil should also assume reduction commitments. This poses a formidable challenge in the consensus (that is long overdue) toward solving the problem of climate change.

The ozone layer regime has, however, successfully resolved the North-South dichotomy by allocating a fair share of responsibility to both groups and implementing the same, which can also be adopted in the climate change regime. It is important to note that there exists a very clear difference between ozone and climate problems, and hence mechanisms devised under the Montreal regime cannot be directly transplanted to the climate change regime. But, these good practices can be taken as lessons in the design of future agreements in the climate regime.

As discussed above, sequential approach to developing nations, enhancing participation and compliance, redesigning the financial assistance and technology transfer regimes, and re-structuring the global politics of climate change are some of the solutions that can positively contribute towards an effective climate change regime. This enhances the applicability of the principle of 'common but differentiated responsibility' and allocates equitable share of responsibilities both for the developed, emitter developing and non-emitter developing nations. Accordingly, developed nations are expected to assume

${ }^{241}$ Donald Kaniaru, Rajendra Shende, Durwood Zaelke, (2008). Landmark Agreement to Strengthen Montreal Protocol Provides Powerful Climate Mitigation, 8 Sustainable Dev. L. \& Pol'y 46.

242 Jorge E. Vinuales, (2010). Legal Techniques For Dealing With Scientific Uncertainty In Environmental Law, 43 Vanderbilt Journal of Transnational Law 437 , at $453-455$. 
immediate reduction commitments, pledge economic assistance and facilitate technology transfer to developing nations under the condition that developing nations will assume responsibility later. Under such schemes, developing nations will not be totally relieved from commitment but will assume some responsibility based on their historic share of responsibility, economic capacity, amount of current emission and rank on the human development index. ${ }^{243}$

Meanwhile, the politics of climate change need to be redesigned and local governments should enhance the awareness of their public, industry and labor associations; they should also stand firmly against pressures on the climate regime. ${ }^{244}$ Adequate fund is apparently needed for research and development towards renewable (and low-cost) energy alternatives and minimizing transition costs. Working toward energy alternatives is underway in both developed and developing nations ${ }^{245}$ as an integral part of the green movements in all countries. These pursuits indeed mark the advent of new value systems and development paradigms the pace of which determine the prospects and magnitude of achievements in the climate change regime.

${ }^{243}$ See, Human Development Report, supra note 57, at 40-41, at 229-242, and 355-372; Mumma and Hodas, supra note 166, at 638-642; see also Posner and Sunstein, supra note 166.

${ }^{244}$ Reports show that public awareness is increasing. For instance, in USA "The idea of buying green has become popular, and books and magazine articles on going green are everywhere" and 'green' is becoming most popular trade mark. Roger R. Martella, Jr. (2010). Climate Change Along The Northeast Corridor: How Washington And New York Are Approaching And Preparing For Greenhouse Gas Controls, 18 N.Y.U. Envtl. L.J. 14, at 31-32.

${ }^{245}$ In the renewable energy sector, for instance, developing countries are investing more than developed countries where China is in the forefront and India experienced the fastest expansion rate in 2011. Ethiopia also adopted its own green economy strategy with the view of building a climate resilient green economy. See UNEP, (2011). Global Trends in Renewable Energy Investment 2011: Analysis of Trends and Issues in the Financing of Renewable Energy, United Nations Environment Programme and Bloomberg New Energy Finance; Federal Democratic Republic of Ethiopia, (2011). Ethiopia's Climate-Resilient Green Economy: Green economy strategy; The Federal Democratic Republic of Ethiopia Environmental Protection Authority, (2011), Ethiopia's Vision for a Climate Resilient Green Economy available at $<$ www.epa.gov.et/> 